\title{
6. EL RECLUTAMIENTO MILITAR Y SUS IMPLICACIONES SOCIALES EN EL MARCO DE LA CONSTITUCIÓN DE 1845
}

ENRIQUE MARTÍNEZ RUIZ 


\section{SUMARIO}

La Ordenanza de 1837.-Fianzas, sustitutos Y redenciones.-ConSIDERACIÓN LEGAL DE LOS PRÓFUGOS Y DESERTORES.-TIPIFICACIÓN Y CARACTERIZACIÓN DE ESTOS DELINCUENTES.-NOTIFICACIONES OFICIALES DE LA EXISTENCIA DE DESERTORES Y PRÓFUGOS.-MEDIDAS GUBERNATIVAS ANTE LOS DELITOS MILITARES. 
Revista de Derecho Político, núm. 39, 1995, pp. 213-259

\section{EL RECLUTAMIENTO MILITAR Y SUS IMPLICACIONES SOCIALES EN EL MARCO DE LA CONSTITUCIÓN DE 1845}

POR

ENRIQUE MARTÍNEZ RUIZ

En los últimos años es frecuente la aparición de trabajos sobre temas militares que van rellenando uno de los vacíos mayores de nuestra historiografía. Los siglos XVI —especialmente por el prestigio internacional de nuestras armas- y XIX - sobre todo por su significativa intervención en la vida nacional - cuentan con los mayores atractivos en una labor investigadora que ha dado granados frutos $y$ ha actuado de incentivo para extender las áreas de estudio, de manera que, hoy por hoy, es fácil encontrar aportaciones significativas sobre nuestra Milicia, su historia y su proyección en cualquiera de nuestros cuatro últimos siglos de existencia.

En el caso concreto del siglo $\mathrm{XIX}$, la investigación se ha mostrado particularmente fructífera. No en vano se considera el militarismo como uno de sus rasgos más definitorios. Hechos como los pronunciamientos, las guerras carlistas, las acciones africanas o el ocaso imperial han gozado de actualidad casi permanente. $Y$ no digamos nada de la presencia de los militares en el poder, que ha permitido expresiones tan rotundas como el régimen de los generales, de especial aplicación al periodo que aquí nos ocupa'.

El resultado ha sido alentador, pues junto a los "clásicos" militares de siempre, se han situado obras pioneras en su dia, como las de COMELLAS $^{2}$, HEADRICK ${ }^{3}$, MARTÍNEZ CAMPOS ${ }^{4}$, BUSQUETS ${ }^{5}$, etc., con alcances

'PABón, J.: "El régimen politico de los generales", en Narváez y su época, Madrid, 1983; vid. también La subversión contemporánea y otros estudios, Madrid, 1971.

Comellas, J. L.: Los primeros pronunciamientos en España, Madrid, 1958.

HeAdaICK, D. R.: Ejército y política en España (1866-98), Madrid, 1961.

Martinez Campos, C.: España bélica. Siglo XIX, Madrid, 1961. 
y contenidos muy distintos y de desigual suerte en su proyección posterior, pero preparatorios en conjunto de trabajos como los de CHRISTIANSEN, E. ${ }^{\circ}$, FERNÁNDEZ BASTARRECHE ${ }^{7}$ o PAYNE ${ }^{8}$, por citar los más habituales en cualquier relación bibliográfica sobre el particular y que en su momento mostraron la viabilidad de una línea de estudio que llega hasta hoy con aportaciones tan significativas como las ofrecidas por ALONSO BAQUER ${ }^{9}$, CARDONA $^{10}$, CASADO BURBANO $^{11}$, BALLBÉ $^{12}$, SECO $^{13}$ y la de CEPEDA GÓ$M E Z{ }^{14}$, un agudo análisis especialmente valioso por cuanto viene a poner de relieve el enraizamiento en el siglo XVIII de facetas del militarismo que se consideraban hasta ahora como especificas del siglo XIX, en función de un enfoque cuyas limitaciones puede comprobar cualquiera que se tome la molestia de hojear las aportaciones que se vienen registrando en la producción historiográfica del siglo XVIII ${ }^{15}$ y que demuestran cómo las manifestaciones del militarismo decimonónico no son tan espontáneas como pensábamos hace unos años, pues sus orígenes, más o menos claramente, podemos rastrearlos en el siglo XVIII ${ }^{16}$.

En esta ocasión vamos a referirnos al reclutamiento militar, uno de los aspectos más olvidados en la bibliografía especifica, pese a ser un te-

5 Busquets, J.: "Los militares y la sociedad decimonónica», en Historia social de España. Siglo XIX, Madrid, 1977.

- Christiansen, E.: Los orígenes del poder militar en España, Madrid, 1974.

7 Fernández Bastarreche, F.: El ejército español en el siglo XIX, Madrid, 1978.

B PAYNE, S. G.: Ejército y sociedad en la España liberal (1808-1936), Madrid,

1977.

9 Alonso Baquer, M.: El modelo español de pronunciamiento, Madrid, 1983.

10 Cardona, G.: El poder militar en la España contemporánea hasta la guerra civil, Madrid, 1983.

${ }_{11}$ Casado Burbano, P.: Las fuerzas armadas en el inicio del constitucionalismo español, Madrid, 1982.

12 BALLBÉ, M.: Orden público y militarismo en la España constitucional (1812-1983), Madrid, 1983.

Madrid, 1984.

13 Seco Serrano, C.: Militarismo y civilismo en la España Contemporánea, 1990.

14 CePeda Gómez, J.: El ejército en la política española (1787-1843), Madrid,

15 Una buena muestra de lo que decimos son los trabajos de GIMÉNEZ LóPEZ, E., de los que sólo mencionaremos uno especialmente consistente: Militares en Valencia (1707-1808), Alicante, 1990.

${ }_{16}$ Nosotros hemos llamado la atención al respecto en dos de nuestros trabajos: «La presión de las guerras revolucionarias sobre el ejército español. Oficialidad y tropa en el cambio de siglon, presentado al Coloquio Internacional Les revolutions iberiques et ibero-americaines a l'aube du XIXe siècle, Bordeaux, 2-4 julio 1989 , cuyas actas han sido publicadas con el mismo título del Coloquio por el C.N.R.S., París, 1991, págs. 91 y ss., y "La vertiente política de la crisis del reinado de Carlos IV", ponencia presentada en la / Reunión Científica de la Asociación Española de Historia Moderna, Madrid, diciembre 1989 y publicada en La España de Carlos IV, Madrid, 1991, págs. 141 y ss. 
ma de enorme importancia por su incidencia social ${ }^{17}$ y que a mediados del siglo XIX, en plena vigencia de la Constitución de 1845, adquiere sus perfiles más acusados y consagra unos mecanismos legales que afectan directamente la sensibilidad de la sociedad española, sobre todo en sus clases medias y populares, toda vez que dichos mecanismos permiten eludir el sorteo o el servicio militar a los que poseen suficientes medios económicos como para comprar un sustituto o redimirse en metálico. De esta forma, la desigualdad social se mostraba especialmente injusta, pues la diferencia entre "pobres" y uricos" se volvía dramática al permitir que éstos pudieran no contribuir con sus efectivos humanos a los compromisos bélicos españoles. $Y$ podrán hacerlo dentro de la más pura legalidad gracias a la Ordenanza de 1837, que en unos aspectos se mantiene dentro de la tradición $y$ en otros estaba llamada a tener un gran predicamento posterior, dado el dilatado periodo de vigencia que tuvo $y$ lo adecuado de su normativa a los planteamientos del liberalismo vigente entonces respecto a la contribución de la sociedad a las necesidades militares de la época.

\section{LA ORDENANZA DE 1837}

La Ordenanza de 1837 es un texto fundamental para el reclutamiento y reemplazo de nuestro ejército; sus directrices, como hemos apuntado antes, van a servir de guía hasta entrado el siglo $X X$, aunque su tenor será modificado en los años siguientes con unas disposiciones gubernamentales que van a matizar, renovar y completar sus prescripciones; modificaciones que se imponen por presentarse casos no previstos,

17 Hace tiempo ya, abordamos algunas de las implicaciones sociales del reclutamiento militar en unas páginas que titulábamos "Desertores y prófugos en la primera mitad del siglo XIX", en Hispania, n. 107, 1967. Más recientemente volvimos sobre el tema: "La celebración de quintas, una cadencia temporal en la España del Antiguo Régimen", en Revista de Historia Moderna (Alicante), n.o 11, 1992, págs. 215-226.

Véase igualmente Fernández Bastarreche, F.: "La cuestión de las quintas en el Sexenio Revolucionario", en Revista de Historia Militar, n. 43, 1977, y los trabajos de N. Sales, que utilizamos y citamos más adelante.

En lo que se refiere a las disposiciones gubernamentales que regulan el reclutamiento, el trabajo mas sistemático - que nosotros conozcamos- es el realizado por MaQueda ABREU, C.: Aspectos legales del reclutamiento militar español en el siglo XIX (1814-1850), Memoria de Licenciatura, inédita aún, presentada en la Universidad de Granada, de la que la autora ofreció una parte en su artículo "La restauración de Fernando VII y el Reclutamiento Militar», en Revista de Historia Militar, n.. 62, 1987. 
por situaciones especiales y por la necesidad de renovarla para adaptarla a las circunstancias del momento ${ }^{18}$.

Los trámites que habian de seguirse para determinar el cupo de mozos correspondiente a cada pueblo en el reclutamiento anual de la nación tienen claras semejanzas con la Ordenanza de 1800 y han de ajustarse a un calendario determinado que en lo sucesivo habrá que respetar exactamente para evitar entorpecimientos a la realización de las distintas fases de la quinta. En el mes de enero se hacía el padrón de los pueblos y en él se incluían todos los mozos presentes y ausentes; en los lugares donde hubiese mucho vecindario podría hacerse - como se autorizaba también en 1800 - una división por distritos para todo lo relativo a reemplazos, según el criterio de los Ayuntamientos y Consejos provinciales, teniendo en cuenta que cada distrito se compondría de unas ciento cincuenta personas aproximadamente y funcionaba con entera independencia; igualmente si un Ayuntamiento tenía varias poblaciones en su jurisdicción, en cada una y aisladamente se haría el sorteo, funcionando con autonomía en lo relativo a quintas. Hecho el padrón, se hará un extracto que refleje el número de mozos que hay, las autoridades municipales lo firmarán, como responsables de su exactitud y veracidad, y lo enviarán a la Diputación provincial dentro de los primeros ocho días de febrero.

Recibidos todos los extractos, se formará un alistamiento para el reemplazo, sacado del padrón general, con los españoles, solteros y viudos sin hijos, que el 30 de abril inclusive del año en que se hace el alistamiento tengan dieciocho años cumplidos y veinticinco sin cumplir y los "casados y ordenados in sacris" que no hayan cumplido veintidós años; al margen de los nombres irá la edad respectiva. Como en la Ordenanza de 1800 , se encargaba que los curas párrocos, con cuantos datos puedan aportar de los alistados, concurrieran a las reuniones del Ayuntamiento para tal efecto, reuniones que serian abiertas. Una vez confeccionadas las listas de los comprendidos en el alistamiento, se fijarán en los lugares públicos a fin de que se compruebe la exactitud de su contenido.

La primera fiesta de marzo será la fecha en que se lean en público las listas con las correcciones oportunas, y el Ayuntamiento escuchará

18 El ejemplar utilizado por nosotros de la Ordenanza para el reemplazo del Ejército de 2 de noviembre de 1837, Madrid, 1847, es uno de los prontuarios militares de la época que además contiene todas las reformas posteriores hasta 1846. La ordenanza se compone de 17 capítulos con 114 articulos, fue decretada por las Cortes el 31 de octubre de 1837 y sancionada por la Regente María Cristina de Borbón en 2 de noviembre de ese mismo año. 
cuantas aclaraciones se le hagan, resolviendo los casos que pueda en el acto y los que no, se harán constar para su resolución posterior. Si en un día no puede concluirse la lectura, se continuará hasta su conclusión en las festividades de marzo.

Los que deseen poner reparos a las conclusiones municipales finales, lo harán por escrito antes de transcurridos dos días de la terminación y en ese escrito reclamarán el certificado que la acredite, certificado que recogerán dentro de los tres días siguientes y diez más tarde como máximo acudirán al Consejo provincial presentándolo; si los plazos se pasan, la queja no se cursa. Si el Consejo puede decidir, lo hará inmediatamente; si no, fijará un plazo para ello. Caso de que un mozo figure en el padrón de dos pueblos, el Consejo determinará, si los pueblos no se ponen de acuerdo, a cuál pertenece.

Realizado así el alistamiento, se confeccionará una lista que comprenda a los mozos de 18 y 19 años, otra con los de 20 y 21 , otra con los de 22 , otra con los de 23 y una última con los de 24 . A las siete de la mañana del primer domingo de abril empezará el sorteo en todos los pueblos y se concluirá al ponerse el sol; si no ha habido tiempo suficiente se continuará en los días siguientes. El sorteo comenzará por los mozos más jóvenes, es decir, por los de 18 y 19 años, para lo que se pondrá cada nombre en una papeleta; las papeletas serán todas iguales, $y$ en otras semejantes se escribirá con letra tantos números como mozos sean. Las papeletas se colocarán en el interior de bolas del mismo tamaño y color, para introducirlas en dos globos, uno conteniendo todas las de los nombres $y$ otro con las de los números, leyéndose al mismo tiempo que se introducen. Luego los globos se moverán para que se mezclen bien, y dos niños menores de diez años de edad sacarán cada uno una bola de su globo respectivo; ambos personajes sacarán la papeleta y leerán el nombre y el número, que podrán ser comprobados por cuantos quieran, siendo siempre los Ayuntamientos los responsables de la legalidad y exactitud del acto.

Luego se hará un nuevo sorteo con los mozos de 20 y 21 años; concluido éste, otro con los de 22 y después otro con los de 23, terminando con otro para los de 24. Cada uno de estos sorteos tendrá un acta independiente. La numeración de los mozos empezará siempre con el número 1 y llegará hasta la cifra que marque el número de quintos comprendidos en cada sorteo. Terminados los sorteos y leídas las actas, no se admitirá ninguna reclamación sobre inclusión o exclusión de individuos; si alguno de los sorteados, por haber hecho la reclamación a tiempo, es excluido, se sacará del alistamiento y todos sus siguientes descenderán un puesto; si hubiese que incluir a alguno después de realizado el sorteo, éste se declarará nulo y se verificará otro con todas las formalidades. En 
este sorteo irán todas las papeletas en blanco, excepto la del nuevo sorteado; cuando le salga, volverá a sortear su número con el mozo que lo poseía en el sorteo anterior, incluyendo para ello ese número y el siguiente; sorteado de nuevo, todos los mozos con números posteriores ascenderán un número. Si son varios los mozos a sortear se seguirá el mismo procedimiento.

Las Cortes dispondrán en los primeros diez dias de marzo de los estados de población para considerarlos a la hora de hacer los cupos por provincia. Los Ayuntamientos y particulares podrán protestar en las Diputaciones provinciales, sin retrasar el mecanismo del servicio, de cuantas ocultaciones o fraudes se hayan cometido, dando el pueblo que ocultó parte de la población el número de quintos que proporcionalmente corresponden a la parte ocultada y que se rebajarán del cupo de la provincia si el sorteo no está hecho, y si lo está, se rebajará del cupo siguiente.

Las Diputaciones provinciales, una vez recibido el decreto de las Cortes $y$ dentro de los ocho días siguientes, fijarán entre los pueblos de la provincia respectiva el reparto proporcional. El sorteo de ese reparto se hará por enteros y décimos, según las fracciones que resulten; dichas fracciones tendrán que completarse entre los distintos pueblos hasta formar enteros. Si algún pueblo no pudiese dar un entero, su población se reunirá con la de otro u otros para completarlo. Para establecer el orden en que irán aportando sus décimos, se introducirán en un globo diez papeletas con los nombres de los pueblos, poniendo por cada uno tantas papeletas como décimos le correspondan y en otro diez papeletas numeradas del uno al diez. El pueblo que resulte con el número 1 dará el soldado, que tendrá 18 ó 19 años; si no lo hubiere, se cogerá del pueblo siguiente, y si tampoco lo hay, del siguiente, y asi sucesivamente. Una vez realizado el repartimiento total, se imprimirá y comunicará a los pueblos, poniendo en una casilla el número de habitantes del pueblo $y$ en otra el de quintos que debe dar.

Recibida la comunicación en los pueblos, los Ayuntamientos citarán a todos los mozos alistados para presentarse en el primer día festivo, siempre que puedan transcurrir más de tres días a contar desde el de recepción de las listas, y además se citará personalmente a los mozos que tengan los primeros números y los sucesivos hasta un número cuádruple al cupo de quintos que al pueblo corresponde. Llegado el día de las convocatorias, se llamará al mozo de 18 ó 19 años que tenga el primer número; se medirá a la vista de los concurrentes, y si no tuviese cinco pies menos una pulgada (1,375 ms., aproximadamente), será dado como bajo de talla y se llamará al mozo que le sigue, y así sucesivamente; cuando pase la talla, se analizarán las demás condiciones necesarias. Si exis- 
tiese alguna razón para ser excluido la expondrá y se la aceptará en el acto, al igual que las razones de los contradictores, junto con los justificantes que se presenten para considerarlos en ese mismo momento y el Ayuntamiento por "pluralidad absoluta de votos declarará al mozo soldado o excluido" "19. Si la exclusión es por inutilidad física, se aceptará así por todos; si no se admite, se procederá al oportuno reconocimiento.

Sólo serán excluidos del servicio: los inútiles; los que antes del día 1. del año del reemplazo estén inscritos como hombres de mar y estén dentro de dos leguas de distancia de las costas y se ejerciten en la pesca y navegación; los carpinteros inscritos en las brigadas de los arsenales; "los licenciados por haber cumplido el tiempo de su empeño"; los que se hayan buscado legalmente sustitutos; los que hayan pagado para redimirse; los que lleven dos años en la Milicia provincial, habiendo sido quintados para este servicio; los que pertenezcan a esa milicia y estén sirviendo fuera de la provincia al hacerse el llamamiento; el hijo único que tenga a su cargo al padre indigente o de más de sesenta años; el hijo único de viuda y el que mantenga a su madre pobre o si el marido está cumpliendo una pena de la que le resten más de seis meses; el nieto único que mantenga a su abuela o abuelo indigentes, siendo éste de más de sesenta años o impedido y aquélla viuda; el hijo único natural que mantenga a su madre; el hermano que mantenga a sus hermanos o hermanos huérfanos de padre y madre si los protegidos no son varones, y si lo son, que no tengan dieciséis años; el hijo de madre viuda o casada que tenga otro hijo sirviendo en el ejército.

Si algún mozo alistado emplea algún fraude para eximirse, se le recargará de seis meses a dos años de servicio. Si alguno se inutiliza voluntariamente, padecerá de dos a cuatro años en obras públicas, teniendo presente que si le toca como soldado no se le reemplazará por el quinto siguiente.

Tallado el primer mozo de 18 ó 19 años, se pasará al siguiente y de esta forma se continuará hasta terminar con todos. El acto empezará a una hora discreta de la mañana y se terminará a la puesta de sol, tras un intervalo de una hora a medio día. Si no ha habido tiempo suficiente se continuará los días siguientes, aunque no sean festivos.

Tres dias después de concluido el llamamiento se dirigirán hacia la capital los soldados y suplentes, presentándose en ésta lo antes posible; irán a cargo de un comisionado del Ayuntamiento, que verificará la entrega y tendrá la ayuda de costa que se estime oportuna con cargo a los

19 Ordenanza..., pág. 17. El entrecomillado siguiente, en pág. 19. 
fondos públicos, de los que los soldados y suplentes recibirán dos reales por día desde el que salgan del pueblo hasta la entrega en la capital. Dichas cantidades las recogerá el comisionado del Comandante de la Caja de Recluta y las devolverá a los fondos del municipio.

Si un prófugo es declarado soldado o suplente se le sustituirá por otro mozo y no se le abonará el tiempo que éste sirva por él; se le abonará al sustituto si le toca en otro reemplazo. El comisionado llevará una certificación con todos los trámites realizados y otra en la que conste nombre, día de salida de los soldados y suplentes y las filiaciones de cada uno. La entrega será pública, en presencia de los suplentes y de cuantos quieran presenciarla; a la vista de todos se hará el reconocimiento y demás formalidades necesarias para su aceptación. Si alguno es desechado por cualquier motivo, se le sustituirá por el suplente respectivo. Hecha la entrega, serán preguntados si tienen alguna queja que formular contra el Ayuntamiento; el consejo las aceptará, y con la presencia de las personas y justificantes necesarios determinará si la queja es o no procedente. Los suplentes no entregados volverán al pueblo, recibiendo también dos reales por día de estancia en la capital y por cada uno de los de vuelta, que cobrará el comisionado al jefe de la Caja de Recluta, de las que habrá una en cada capital de provincia a cargo de un oficial. Los consejos provinciales están autorizados a multar a "los Alcaldes, Ayuntamientos, secretarios de éstos, facultativos y otras personas que hayan faltado a la observancia y exacta ejecución de esta ordenanzan ${ }^{20}$.

El servicio podrá desempeñarse por medio de sustitutos, pero la sustitución será de carácter individual. Los sustitutos habrán de presentarse en los cuerpos a que sus sustituidos han sido destinados en el plazo de un mes a contar desde el dia en que éstos fueron declarados definitivamente como soldados; también podrán presentarse en las cajas de quintos. La sustitución se hará entre los mozos sorteables de una misma provincia, por cambio de números o por licenciados del ejército o milicias. "En el primer caso deberán los sustitutos ser menores de 25 años, solteros o viudos sin hijos que no tengan pendiente recurso de excepción". El sustituido en los reemplazos siguientes ocupará el lugar del sustituto. Cuando los sustitutos sean licenciados, tendrán menos de 30 años y sin mancha su hoja de servicios y su conducta ciudadana. Los sustituidos quedarán responsables de los que van en su lugar y se incorporarán a filas si éstos desertan antes de pasar un año contado a partir del día de la entrega. Cuando sea recibido el sustituto, se extenderá un documento acreditativo de ello. La sustitución se puede hacer cuando quieran y las condiciones de la misma se acuerdan entre las partes interesadas.

${ }^{20}$ Ordenanza..., pág. 30. El entrecomillado siguiente, pág. 31. 
La Ordenanza termina estableciendo que los mozos que cumplan 18 años no tendrán empleo ni cargo público sin demostrar que han cumplido con esta ley. Los reemplazos extraordinarios se verificarán en la misma forma que los ordinarios. Esta disposición invalida las de «27 de octubre de 1800, la instrucción adicional de 1819 y todas las demás disposiciones dadas hasta ahora sobre el modo de ejecutar los reemplazos" ${ }^{21}$.

Como hemos podido comprobar, en la Ordenanza persisten los dos sorteos: el del Ejército y el de Milicias. Se mantiene también el sistema, molesto e impopular, de los décimos. Pero lo más destacable es la reglamentación de las sustituciones y de las redenciones, con lo que entraban en juego plenamente todos los elementos que nutren la animadversión popular a las quintas. La desigualdad en beneficio de los acomodados quedaba reconocida legalmente, el "tributo" o "la contribución de la sangre" se convertirá en una pesada y dramática carga sobre las clases populares, especialmente hiriente en tiempos de guerra. Volveremos más adelante sobre estas cuestiones.

Como la Ordenanza establecía las bases de todas las operaciones del reclutamiento, pero no preveia todas las variantes que sobre el particular pudieran presentarse, necesitó una legislación complementaria que la perfilara y definiera aún más, legislación que va a apareciendo a lo largo del reinado de Isabel II ${ }^{22}$.

El cupo a cubrir en las quintas por cada pueblo estaba en relación inversa al número de voluntarios que dicho pueblo aportaba, de modo que el número de quintos era menor cuanto mayor era el de voluntarios. Esta realidad fue origen de algunos fraudes, porque los pueblos aumentaban falsamente el número de los que se presentaban voluntariamente para que asi se redujese la cuantía de su cupo, lo que hizo necesaria una ley que garantizase la legalidad de esta operación, que se publica el 9 de marzo de 1852 y en la que se establece para mantener la legalidad y ve-

${ }^{21}$ Ordenanza..., pág. 38. Sigue un modelo de filiación y la copia literal de cuantas órdenes y decretos posteriores perfilaban algún punto de los contenidos en la Ordenanza.

${ }_{22}$ Estas leyes complementarias van apareciendo en los Boletines Oficiales del Ejército, en la Gaceta, en los Boletines Provinciales y se circulan como instrucciones a las autoridades civiles. Todas las aparecidas hasta 1846 están recogidas y publicadas, juntamente con la Ordenanza, en la edición manejada por nosotros ya lo hemos dicho... Las restantes hasta el final del reinado se pueden espigar en las publicaciones citadas, aunque su consulta resulta más cómoda en los tomos de los Reales Decretos (tres tomos por año —uno al final de cada trimestre-, publicados en Madrid). 
racidad de las relaciones que por cuenta de sus cupos presentan las cajas de los pueblos en las quintas sucesivas referentes a individuos que se hallan sirviendo como voluntarios, no se admitirán otros documentos acreditativos de la existencia de los mismos que las certificaciones de los jefes de los Cuerpos en los que están cumpliendo su servicio militar. A fin de que en el reclutamiento de ese mismo año tenga ya vigor esta disposición, se fija el plazo de un mes para la reunión de las certificaciones de los que sirven en la península, cuatro meses para los de La Habana y Puerto Rico y un año para los de Filipinas. Tales documentos se presentarán el día fijado por la ley para la declaración de soldados ${ }^{23}$.

Para dar una mayor fluidez y agilidad a las operaciones de recluta, se publicó el 20 de diciembre de 1854 un decreto que contenía el establecimiento de banderas móviles para el reclutamiento voluntario el ejército ${ }^{24}$.

Pese a todos los intentos por mantener dentro de la más estricta legalidad la tramitación y transcurso de la quinta, no faltaban anomalías y falsificaciones de resultados con las que se pretendia beneficiar a algún mozo perjudicando a los que le seguian. Estos fraudes debieron ser frecuentes. Como muestra puede servirnos el denunciado en Salamanca, donde el corneta de la 3. - Compañia de la Guardia Civil del 8.ำ Tercio, Bernardo Garrido, habría de recibir cuatrocientos ochenta reales si lograba que los encargados de tallar los quintos admitían a uno que estaba dudoso para que quedase libre el que le seguía; el corneta fue condenado a extinguir el tiempo de su empeño en el Regimiento Fijo de Ceuta y se le impone una multa de la misma cuantía que el soborno, que se entrega al Jefe Político de Salamanca para que la emplee en el caso de caridad que crea más oportuno ${ }^{25}$.

En efecto, la talla de los quintos era uno de los trámites que más se prestaba a fraudes, por lo que resultaba de especial interés para todos que se procediera en él con la regularidad más absoluta. Por ello se pretende en algunos lugares que sargentos y cabos de la Guardia Civil estu-

${ }^{23}$ Recopilación de las Reales Órdenes y Circulares de interés general para la Guardia Civil, t. VII, Madrid, 1852, pág. 24. La Recopilación es una publicación tan completa como útil, cuyo manejo resulta para nosotros muy cómodo sobre este particular.

${ }^{24}$ Dicho decreto está distribuido en 23 artículos, en los que se recoge completamente la misión y funcionamiento de estas banderas móviles. Vid. Recopilación..., t. X, Madrid, 1954, págs. 67-71.

${ }_{25}$ Recopilación..., t. IV, Madrid, 1849, págs. 235-236. Sentencia recogida en la Circular de 5 de mayo de 1849, emitida por la 1." Sección de la Secretaria General de la Guardia Civil. 
vieran presentes en dichos actos, pero tal pretensión se impidió por el Ministerio de la Guerra, pues se consideraba empleo impropio de la nueva institución de seguridad y en la Ordenanza se preveian todo tipo de facilidades para quien quisiere comprobar la veracidad y legalidad de todos los trámites de la quinta ${ }^{26}$.

\section{FIANZAS, SUSTITUTOS Y REDENCIONES}

A partir de 1837, la sustitución y la redención son medios legales para eludir el servicio militar, pero no estaban al alcance de todos, ya que exigían disponer de ciertos medios económicos. Por entonces ya estaba en práctica un procedimiento para no incorporarse al ejército, procedimiento que se difundiria en los años siguientes obligando a intervenir a los gobiernos con la imposición de las denominadas fianzas, cuya cuantía se sitúa en torno a las 2.000 ptas.

En efecto, uno de los procedimientos más empleados por los mozos para evitar la suerte de quintas era el marcharse al extranjero y a Ultramar y permanecer fuera hasta que desaparecía para ellos la posibilidad de incorporarse al ejército, justificando su ausencia la incomparecencia a filas. En realidad, tal comportamiento equivale al de los prófugos y, para evitarlo, Isabel II firma un Decreto, el 25 de febrero de 1846, tras un informe presentado por el Tribunal Supremo de Guerra y Marina, que prohibia se expidiesen pasaportes para cualquier lugar, español o no, fuera de la Península a todo individuo que estuviese comprendido entre los dieciséis y los veinticinco años, a no ser que asegure la aceptación del resultado del sorteo correspondiente a su quinta mediante la entrega de una fianza reconocida en escritura pública, que deberá ser aceptada y aprobada por el alcalde del pueblo del que es vecino el mozo que quiere ausentarse. La aceptación tendrá lugar una vez oídos, y reconocida su declaración por escrito, los padres, familiares o tutores de tres mozos de la misma edad del que se marcha y "de otros de la inmediatan. La fianza que se entrega se utilizará en la compra de un sustituto, caso de que el mozo que la depositó no se presentase a la verificación del sorteo y no se incorpore al Cuerpo que les corresponda ${ }^{27}$.

${ }^{26}$ Recopilación..., t. V, Madrid, 1850, págs. 53-54, y t. VII, págs. 121 y 105 106.

27 Recopilación..., t. I, Madrid, 1846, pág. 113. 
No obstante, los mozos se las ingeniaban para ausentarse sin pagar la fianza, por lo que se insiste en 11 de febrero de 1852 por medio de una Orden del Ministerio de la Guerra, en la que se determina que en todos los pasaportes que se den para el extranjero a los mozos comprendidos entre los dieciocho y veintitrés años conste el requisito de haber pagado la fianza (el pago de la misma había sido incorporado a la ley de reemplazo, art. 117) y se determinaba igualmente que aquellos que no tuviesen en su pasaporte la cláusula de haber depositado el pago, fueran detenidos ${ }^{28}$.

Pero el asunto no queda zanjado definitivamente. El problema de la marcha a Ultramar no acababa de resolverse y se hace necesaria una nueva disposición. El 3 de diciembre de 1856 aparece un decreto en el que se ordena a los Gobernadores de las provincias ultramarinas no expidan pasaportes a los mozos sujetos a quintas a no ser que estén libres de toda responsabilidad o acrediten haber hecho el depósito; la prohibición se hizo necesaria porque muchos llegados de la Península querían marcharse después a Estados Unidos sin cumplir con el requisito de la fianza, por lo que se ordena se les retenga en Ultramar hasta que acrediten haber hecho el pago, consiguiendo una doble finalidad: evitar fraudes y que los mozos sufrieran un doble desembolso al exigírsele allí también el abono de la fianza; en consecuencia, deberian llevar el certificado de haber pagado en España, en cuyo caso no se les impediría la salida ${ }^{29}$.

La solución que se cree definitiva se da en 1861, dado que en los años anteriores los jóvenes seguían intentando evadir la suerte de quintas mediante su marcha al extranjero. El 17 de julio de 1861 se promulga una ley que contiene unas disposiciones para evitar esa emigración que se reglamenta definitivamente ${ }^{30}$. Sin embargo, tampoco se alcanzaron los resultados que se esperaban con esta ley. Efectivamente, el Decreto de 9 de agosto de 1862 es un mentís rotundo a su efectividad, pues en él se ordenaba a la Guardia Civil y demás fuerzas de seguridad que vigilasen con especial atención las costas de Galicia y Asturias para impedir la salida a los mozos que quieran evitar los sorteos. En dicho decreto se ordena a las referidas fuerzas revisar las cédulas de vecindad de cuantos

28 Recopilación..., t. V., págs. 13-14.

29 Recopilación..., t. VII, págs. 104-105.

30 La Ley de 17 de julio de 1861 recoge y completa todo lo legislado con anterioridad sobre el particular, a lo que añade la casuistica que con el tiempo se había planteado; por ello se emite con la pretensión de que sea definitiva. Vid. Boletín Oficial del Ejército del mismo mes y año y la Gaceta de dos fechas después que la ley. La petición a la Guardia Civil para que colabore en su cumplimiento, en Recopilación..., t. IX, Madrid, 1854, págs. 171-172. 
salian y comprobar si las condiciones en que se efectuaba la salida eran las legales ${ }^{31}$.

El contenido del anterior decreto nos pone de relieve que la sangría del reclutamiento era considerable, que no se lograba la forma de impedirlo y que los interesados siempre encontraban un medio para eludir el depósito de la fianza, unas veces por la salida clandestina del país (causa de que en Ultramar se presente el mismo problema y se impida salir a los españoles jóvenes si no demuestran haber hecho el pago prefijado por la ley), bien al extranjero, bien a las posesiones españolas, siendo el viaje a estas últimas el más utilizado, ya que en ellas las posibilidades de pasar a otro país sin entorpecimiento eran mayores que en la Península. Otras veces, la salida se produciría por corrupción de los funcionarios encargados de estos asuntos y en algunos casos por negligencia o ignorancia de quienes habian de impedirlo. Sea como fuese, el caso es que se precisó la llamada a las fuerzas de seguridad, especialmente a la Guardia Civil, para que con su actuación y vigilancia se cortase este fraude.

También es significativo el hecho de que se éncargue la vigilancia de la costa del noroeste de España, de lo que podemos deducir que estas costas registraban el índice más elevado de hombres que salían en edad militar sin pagar fianza y que las salidas ilegales eran frecuentes en barcos que no tocaban puerto o que, si atracaban, recogían sus pasajeros ilegales a horas intempestivas. Pero tan importante es lo que entre líneas podemos ver: un aspecto nuevo de la emigración gallega y asturiana en el siglo XIX. Su cuantía, lógicamente, no debió ser muy considerable y su influencia en la totalidad de la emigración no pesaría gran cosa, lo que no resta interés a conocer con exactitud su evolución.

Los otros dos procedimientos para eximirse del servicio militar, la compra de sustitutos - que podía ser individual o colectiva- y la redención mediante pago al Estado de una determinada cantidad, tienen una repercusión gravísima en el terreno social al contribuir a marcar aún más la diferencia de clases. Los agricultores y labradores pobres veían impotentes cómo el gobierno, a través del ejército, les arrancaba a sus hijos para sumergirlos en unas guerras lejanas, mientras los hijos de los acomodados seguían en el pueblo. Es fácil imaginar el ambiente enrarecido que en los pueblos se formaba a medida que se iban notificando las bajas a los Ayuntamientos o familiares. El campesino veía que era un precio muy alto el que tenía que pagar en esa guerra, precio que se endurecía aún más cuando veía a los hijos de los adinerados, para quienes la

31 Recopilación..., t. IX, págs. 153-154. 
guerra se reducía a un desembolso económico, pequeño para sus posibilidades. Gran problema que los políticos españoles del siglo XIX no acertaron a ver, cegados quizás por la penuria del Erario público. En última instancia, tal vez fuera creado por el sentido económico del liberalismo que se radicaliza y su postrera expresión consistiera en las escenas que se repiten en las ciudades pequeñas cuando los "soldaditos españoles" embarcaban para Cuba o Marruecos. Sus familiares, para retenerlos a su lado, no dudaban en empeñar cuanto tuviesen, hipotecar su finca o recurrir a cualquier otro medio a su alcance siempre con el mismo resultado: mantener y agravar la enrarecida atmósfera que se respiraba en los pueblos. El descontento, a veces, estallaba violentamente, y pueblos enteros se oponian por la fuerza a que se llevase a cabo la quinta, considerada «impuesto de sangre para los pobres e impuesto en dinero para los ricos", con lo que se dividía la sociedad en dos bandos, adinerados y desheredados ${ }^{32}$.

El comprar a un individuo para que sustituyese a alguno de los que debían incorporarse a filas fue un recurso frecuente, como lo prueban los decretos y órdenes relativos al reclutamiento que aluden a ello. Pero la recepción y la permuta del designado por el sustituto estaba indicada de una forma bastante vaga y a lo largo del reinado de Isabel II aparecen unas disposiciones que tratan de reglamentarla, según dice una orden sobre las fianzas, que destina el importe de las mismas a "la compra de un sustituto, en el modo y forma que hoy se halla establecido, o en adelante se estableciese" ${ }^{33}$.

De todos los trámites para la sustitución se encargaban los Ayuntamientos respectivos y ellos enviaban los documentos de la actitud legal de los sustitutos a los jueces de primera instancia ${ }^{34}$. Poco después, $y$ como consecuencia de las necesidades que plantea el reclutamiento de 1848 , se publica una orden de 20 de mayo de este año en la que se determinan las formalidades que seguirán los Consejos provinciales "para admitir a los interesados en el reemplazo de 1844, la subrogación del depósito de cuatro mil doscientos rs., que consignarán como garantía de sus sustitutos". Como la cuantía de este depósito no está al alcance de todos, muchos sustituidos piden se pueda hacer mediante hipoteca de sus bienes, a lo que se accede ${ }^{35}$.

32 Sales de Bohigas, N.: "Some Opinions on Exemption from Military Service en Nineteenth Century Europe", en Comparative Studies in Society and History, vol. X, n. 93,1968 , págs. 261-289.

${ }_{33}$ Recopilación..., t. I, pág. 113. Orden de 26 de febrero de 1846.

34 Decreto de 3 de abril de 1845; Recopilación..., t. I, págs. 58-59.

35 En la legislación que tenemos a la vista no se vuelve a aludir a esta cuestión; nosotros pensamos - considerando que muchas disposiciones de este perío- 
Otro problema que plantean los sustitutos es el de su mantenimiento hasta el lugar de su incorporación. No habia un criterio general y unánime sobre este asunto hasta que en 21 de julio de 1849 se decreta que sean socorridos por las familias de los sustituidos, los cuales correrán con su manutención hasta el momento en que el ejército se haga cargo de ellos ${ }^{38}$.

La reglamentación definitiva de la admisión de sustitutos llega en 1858, pues el 27 de mayo se promulga una ley con las reglas para dicha admisión, y es la que se utilizará en lo que queda del reinado. Como en otros aspectos, esta ley parte de la base legislativa anterior que se ocupa de esta cuestión, introduce algunas innovaciones y pone a punto lo concerniente a la sustitución ${ }^{37}$.

Señalaremos también que se dieron casos en que no se les pagaba la sustitución a los sustitutos cuando cumplían con su empeño, según leemos en el Decreto de 12 de septiembre de 1864: "Frecuentemente sucede que los agentes de las provincias que se ocupan de proporcionar sustitutos abusan de la ignorancia de éstos y los entregan en caja sin darles documento por el cual se comprometen a satisfacer el precio del enganche al término que marca la ley". El mismo decreto pone solución a este fraude encargando la reclamación de dichos documentos a las personas comisionadas para recibir a los sustitutos en las cajas ${ }^{38}$.

Respecto a los sustitutos (cuyo precio osciló mucho, entre las 500 y 1.250 ptas. generalmente, pero que alcanzaba en algunos años y ocasiones cifras superiores), se ha señalado su poco espíritu militar, lo que se traduce en un endurecimiento de la disciplina. El tema tuvo una resonancia literaria considerable y a nivel popular se cantaron numerosos romances que los tenian por protagonistas, de tono generalmente optimista, lo que induce a pensar que "se trata de propaganda encargada por los Ayuntamientos o los gremios que reclutaban voluntarios destinados a sustituciones colectivas de vecinos de la ciudad en cuestión, o de miembros del gremion; este tipo de romances desaparece hacia mediados de

do se dan por un caso concreto y con validez general- que este decreto tendría vigor en los reclutamientos siguientes, pues lo que precisaba era práctica común. $R e-$ copilación..., t. III, Madrid, 1848, págs. 92-94.

36 Recopilación..., t. IV, pág. 279.

37 Antes que estas reglas, en 26 de noviembre de 1855, un decreto precisaba la forma de usar y devolver al depósito que se alude en la nota 35 . Vid. Recopilación..., t. VII, págs. 107-109, y VIII, págs. 101-102.

${ }_{38}$ Recopilación..., t. XX, Madrid, 1865, págs. 288-289. La Ley de 11 de julio de 1885 fijaba el importe de la redención en 1.500 ptas. si el mozo servia en la Peninsula y 2.000 si servia en Ultramar. 
siglo, "cuando desaparecen las sustituciones colectivas, de base cooperativa, organizadas por ciertos Ayuntamientos catalanes... Sin embargo, algunos romances republicanos contra quintas, de los años 1868-1873, hacen pensar también en propaganda de reclutamiento ${ }^{39}$.

Las sustituciones colectivas organizadas a nivel municipal o provincial, bien en metálico (Cataluña, Navarra), bien a cambio de una cantidad fija de voluntarios (País Vasco hasta 1875), tienen una localización que coincide, en general, con las antiguas regiones forales. La cuantía de la sustitución en estas zonas alcanzaba de ordinario cifras en torno al $50 \%$ de los mozos, pero en ocasiones superaba el $90 \%$. Al parecer, los buenos efectos para los vecinos se pierden cuando estas sustituciones desaparecen a causa de varios factores, como las circunstancias políticas de 184043 , los robos de los fondos de las cooperativas de quintas por parte de carlistas y bandidos en sus ataques a los pueblos y la ucomplicidad de los Ayuntamientos con sociedades comerciales de seguros contra quintas, concesionarias del Ayuntamiento a partir de 1844 o 1845 y que después de haber prosperado gracias al hecho solidario, cooperativo, se enardecen y aumentan progresivamente sus precios gracias al monopolio de hecho que el Ayuntamiento les ha concedido, hasta que el margen de diferencia de precios con las sociedades de seguros de quintas comerciales del resto del país viene a ser tan insignificante, que el hecho cooperativo muere, como quien dice, de muerte naturals ${ }^{39}$ bis. La sustitución individual duró bastante más, aunque en la Ley de 11 de julio de 1885 se limita un tanto su alcance. Por norma general, el sustituido quedaba obligado a incorporarse a filas si el sustituto desertaba antes de un año de servicio, so pena de encontrar un nuevo sustituto o pagar en metálico su redención. Ello explica que los pagadores de la sustitución tomaran precauciones para que la suma se hiciera efectiva cuando ya no hubiere responsabilidad para el sustituido, lo cual condujo, en ocasiones, a abusos, como se ha visto.

En cuanto a las redenciones, ha sido puesta de relieve la elevada proporción de exonerados que España tuvo, pese a ser un pais más bien pobre, proporción que entre 1860 y 1871 , por ejemplo, afectó a 1/4 ó 1/5

39 Sales de Bohigas, N.: "Servicio militar y sociedad en la España del siglo $X X$ ", en Sobre esclavos, reclutas y mercaderes de quintos, Barcelona, 1974, págs. 212, nota, y 247; este trabajo es importante para contactar con los problemas que ahora tratamos.

39 bis SALES, "Servicio militar...», págs. 251-252. La misma autora pone de relieve la participación de prohombres de la política y la industria y grandes propietarios (Madoz, Mesonero Romanos, el Duque de Alba, L. Figuerola, etc.) en las sociedades de seguros contra quintos (vid. págs. 258-262). Nosotros no nos detendremos en ello. 
de los quintados. Las consecuencias de esta realidad fueron intensas. "A fin, pues, de librar a los hijos de quintas, familias que estaban lejos de nadar en la abundancia se entrampaban si hacía falta, en la medida de sus posibilidades materiales... Para Pi y Margall, para el marqués de Albaida, patriarca del federalismo, la facultad de redención en metálico era la principal causa de proletarización de las clases medias, de la desaparición de los pequeños capitales en España. Otros políticos ven en la multiplicación de la usura en la España de la Restauración, en la proliferación de cajas de crédito hipotecario a tarifas usurarias, una consecuencia directa de la Ley de quintas. Lo cierto es que todos los años, cuando se acerca la llamada a quintas, los anuncios de cajas de crédito ofreciendo dinero a intereses, públicamente confesados e impresos, del 36 al 60 por ciento anual, se multiplican en los diarios" ${ }^{40}$. Ello explica que para determinados grupos sociales la redención de un hijo, si no queda fuera totalmente de sus posibilidades, equivalga a la ruina de las familias; para otros grupos supone una carga más o menos pesada por la que en ocasiones tendrán que obligarse durante 20 años para pagarla a plazos (esto ocurre con abogados, menestrales, etc.); para las clases altas, tal gasto no afecta al equilibrio presupuestario. En esta realidad descansan en gran medida los beneficios obtenidos por las compañias hipotecarias y de crédito y de seguros contra el servicio militar.

El Decreto-Ley de 2 de julio de 1851 vino a ser el primer intento global más serio para reglamentar la redención, pues en él se fijaban las bases para la admisión de voluntarios y reenganchados en el ejército, quienes cubrirían las bajas de los que se redimieran por 6.000 reales de vellón. De confección muy larga, el siguiente párrafo sirve de síntesis de su contenido: "Según lo dispuesto por la Ley de 18 de junio de 1850 y para que se cumplan bien los artículos $1 . \stackrel{\circ}{1} 129,139,140$ y 141 del proyecto de ley para el reemplazo del ejército que fue aprobado por el Senado en 29 de enero de 1850 en lo concerniente a la redención de la suerte de soldado, mediante entrega de 6.000 rs. de vellón hecha a nombre del mozo que se quiere redimir. Estas cantidades deberán ser depositadas en el Banco Español de San Fernando y serán destinadas sola y exclusivamente a cubrir las bajas del Ejército" " ${ }^{1}$. A partir de esta fecha, las redenciones quedan perfectamente determinadas, $y$ su funcionamiento, según el referido decreto, es el siguiente:

Los comandantes de las cajas de reclutas recibirian de los consejos privinciales el cupo asignado, bien en hombres, bien en recibos de haber pagado en el Banco de San Fernando la cantidad fijada para la re-

40 Sales, "Servicio....", pág. 214.

^Recopilación..., t. V, págs. 37-47. 
dención; los citados comandantes notificarán a los Capitanes Generales el número de quintos y las cartas de pago recibidas. La distribución de quintos entre las distintas armas la seguirá haciendo el Ministerio de la Guerra, para lo cual todos los Directores e Inspectores Generales enviarán una relación de las vacantes que tienen y del número de hombres que han solicitado el reenganche. La saca de quintos la realizarán los comisionados de los Cuerpos que marcharán a las cajas de recluta, y una vez finalizada esta tarea, los comandantes de las mismas darán el resultado a los Capitanes Generales, remitiéndoles relaciones de los hombres entregados y los documentos de los mozos redimidos.

Después de dos meses que como plazo improrrogable se da para obtener la redención, los Capitanes Generales de los distritos remitirán a los intendentes militares de los suyos la relación nominal de los mozos que se han redimido, el pueblo de donde son naturales y las cartillas o recibos de pago, notificándose también al Ministro de la Guerra, y los intendentes de distrito enviarán al Intendente General Militar las cartillas de pago para su empleo adecuado. Finalizada la saca de quintos, los Directores Generales de las armas comunicarán al Ministerio de la Guerra el número de reemplazos realizados, el que se le había señalado y la diferencia, si la hay, entre ambos, pues si la fuerza no estuviera completa, el Ministro cursaría las órdenes oportunas para la admisión de voluntarios, paisanos o licenciados ${ }^{42}$.

Pronto se puso de manifiesto que la cuantía de las redenciones era considerable y fue necesario especificar más clara y detalladamente la forma de ingresarlas y la distribución de los fondos procedentes de las redenciones del servicio militar. Ya no se dedicaría exclusivamente a cubrir las bajas del ejército; en 8 de junio de 1858 sale un decreto con la normativa concreta sobre el particular ${ }^{43}$; dos años más tarde se hizo evidente la necesidad de reglamentar el fondo de redenciones y el 1 de enero de 1860 se promulga un reglamento provisional para la administración e inversión de las cantidades que componen este fondo; el decreto tenía una equivocación que fue rectificada el día 11 del mismo mes y año ${ }^{44}$.

En los años anteriores, especialmente en la Restauración, el destino de los fondos aportados por la redención en metálico es muy diverso: compra de armas, edificación de cuarteles, construcción de barcos, financiación de campañas bélicas, mantenimiento de la Guardia Civil (un

42 El decreto, distribuido en 44 artículos, continúa con las ventajas de que gozarán voluntarios o reenganchados.

43 Recopilación..., t. XIII, Madrid, 1858, págs. 102-103.

4 Recopilación..., t. XIII, págs. 5-13 y 15-16. 
$95 \%$ de sus efectivos son considerados sustitutos para poder dedicar la mitad de este fondo a pagar sus haberes). Ello es debido a las escasas disponibilidades del Tesoro, que deseaba aligerar lo posible sus obligaciones; aquí radica la distinción entre soldado "caro" -el reenganchado, por las ventajas y premios a que tenía derecho- y el soldado "barato" - el recluta, al que sólo había que vestir y alimentar-; por eso, se tenderá en las campañas coloniales, al contrario que en otros países, a enviar reclutas en lugar de voluntarios o veteranos reenganchados, pues si morian éstos la Tesorería tendría que liquidar las primas no amortizadas y pagar orfandades y viudedades. Práctica que fue criticada por los militares españoles, pero las respuestas que recibieron se limitaban a señalar la debilidad del Erario y la imposibilidad de solicitar nuevos impuestos ${ }^{45}$.

Ante tales supuestos, y en función de las realidades que acabamos de ver, los menos pudientes no tenían opción de evitar legalmente la incorporación a filas. Ante ellos sólo quedaban dos caminos, ambos ilegales: uno consistía en promover un tumulto que impidiera la celebración del sorteo: son los motines de quintas (faltos de un estudio que nos informe adecuadamente de los mecanismos y alcances de este fenómeno, del que sólo tenemos información fragmentaria y particular $y$ en el que nosotros no vamos a entrar en esta ocasión), a la postre ineficaces, pues no consiguen otra cosa que retrasar varias fechas la celebración de la quinta, ya que al restablecerse la calma se reanudaba el proceso. Otro, no comparecer en el sorteo y no aceptar su suerte si sale soldado, es decir, convertirse en un prófugo; o bien, como esta conducta perjudicaba a los mozos de la vecindad - la baja del prófugo se cubría con otro joven del mismo pueblo-, cabría la opción para los quintos de incorporarse a filas $y$, ya destinados en sus Cueros respectivos, desertar.

\section{CONSIDERACIÓN LEGAL DE LOS PRÓFUGOS Y DESERTORES}

Si los motines contra la celebración de las quintas son las manifestaciones colectivas de la repulsa al servicio militar, en la actitud de prófugos y desertores debemos ver la muestra de ese rechazo a escala

${ }_{45}$ El trabajo tantas veces citado de Nuria SALEs contiene además unos datos provinciales sobre la intensidad de estos fenómenos que, lamentablemente, la escasez de fuentes no permite completar, pues sólo ha dispuesto de estadisticas detalladas para las décadas 1860-1871 y 1912-1920, cuyo contenido confronta en hábil y rico análisis. Como no vamos a añadir nada al respecto, remitimos nuevamente a él, págs. $216,219-230$ y cuadros y mapas que incluye en apéndices. 
individual: es el último recurso para muchos de eludir el ingreso en filas. Si "la deserción es la compensación a imposibles redenciones en metálico ${ }^{46}$, la misma valoración podemos aplicar a los prófugos. La falta de medios económicos, que impide recurrir a la exención y a la sustitución, es precisamente la que mueve a utilizar todo tipo de recursos para no convertirse en soldado; algunos de esos procedimientos, por pueriles que parezcan, no dejaron de producir su efecto, tales como el aplicar a los varones nombres típicamente femeninos (Encarnación, Trinidad, Concepción...), con lo que los mozos podían con un poco de suerte eludir el sorteo, pero el "fraude» era fácil de descubrir y no dio grandes resultados. En otras ocasiones, el temor a las quintas era explotado por vividores que se aprovechaban de la credulidad popular; tal es el caso, por ejemplo, de Pedro Cobo, que "valiéndose de unas oraciones, hacía creer a los mozos de los pueblos de la Alcarria que jugaban la suerte de soldado, que sacarían el número más alto si tomando el alimento que les daba, las decían en el acto del sorteo; medio del cual hacía uso para estafar a los padres crecidas sumas" y merced a él vivió hasta que fue detenido ${ }^{47}$.

El ambiente adverso que conocemos se traduce a veces en ocultaciones colectivas durante las fechas del reclutamiento, ocultaciones que al repetirse llaman la atención del gobierno y provocan la intervención de las autoridades militares. Como ejemplo puede servirnos el que comunica el Gobernador Provincial de Orense: "Los Ayuntamientos de Padrenda $y$ Lovios hace muchos años que no han cubierto el contingente de los quintos que según la distribución verificada por la Diputación provincial le ha correspondido a cada uno. Esta falta dio ocasión a que por el Gobierno de S.M. se expidieron dos reales órdenes bastante apremiantes para que el servicio referido se realizase con la mayor puntualidad. Los mozos de los pueblos expresados por su proximidad a Portugal se refugian en este reino, y si bien a su ingreso y regreso pudieron ser aprehendidos, las autoridades locales no les persiguen como debieran, y de aquí el que no se pueda cumplir lo mandado por S.M.". Sin embargo, tal evasión cesó ese mismo año con la captura de doce de los mozos implicados $^{48}$.

Como las soluciones colectivas no eran remedio general ni en caso de los motines o sublevaciones ni en caso de encubrimientos, los mozos menos pudientes designados por el sorteo como soldados sólo podian eludir su suerte convirtiéndose en desertores o prófugos; "es sin-

46 Sales, "Servicio...", pág. 221.

47 Boletín Oficial de la Guardia Civil, 1 de diciembre de 1853.

48 Mentor del Guardia Civil, 8 de abril de 1856. 
tomático que algunas regiones donde los redimidos escasean más (Galicia, León) y los sustitutos son abundantes, coincidencia que podría interpretarse como reveladora del espíritu militar, sean las que dan la proporción de desertores más alta de España (hasta el 50 por ciento de todo el contingente), mientras que alli donde redimidos y sustitutos abundan, la deserción es a menudo muy reducida (Cataluña, 3 a 7 por ciento, para medias españolas del 15 al 20 por ciento) $"{ }^{49}$. Realidades que evidencian el juego de intereses, necesidades y exigencias que rodean la cuestión de las quintas $y$ del servicio militar y que contribuyen a explicar la existencia de los prófugos y desertores en nuestra milicia decimonónica.

En la documentación militar del siglo XIX, los términos prófugo y desertor no ofrecen ninguna duda acerca de su contenido. En cambio, en la documentación relativa a orden público se utilizan con frecuencia también las expresiones reos prófugos y desertores de presidio ${ }^{50}$, por lo que tal vez los cuatro términos pueden inducir a error. Para perfilar las figuras delictivas que ahora nos interesan vamos a recurrir a uno de los más completos manuales militares del siglo pasado que dice lo siguiente: "Son desertores del Ejército y Armada los soldados o marineros, ya filiados, que sin permiso de sus jefes abandonan sus banderas, marchándose del punto de su residencia o buque en que están embarcados, o no asistiendo a tres listas aunque permanezcan en el mismo pueblo que el regimiento o partida a que pertenezca, o punto de anclaje de la embarcación. dena.

Los desertores de presidio que se fugan antes de cumplir su con-

Prófugos son los mozos que se ausentan u ocultan para evadir la suerte de soldado, asi como también los que hallándose presos o detenidos en las cárceles se fugan de éstas, burlando la vigilancia de los alcaides.

Unos y otros quebrantan la ley o eluden su cumplimiento" ${ }^{5 ?}$.

En la Ordenanza de 1837, más precisa en muchos aspectos que la de 1800 , se considera prófugo al que no se presente al llamamiento de

49 Sales, "Servicio...", pág. 216.

50 De estos delincuentes nos hemos ocupado en un brevísimo trabajo: "Perfiles de un aspecto de la delincuencia: reos prófugos y desertores de presidio (1844-1867)", en Anuario de Historia Moderna y Contemporánea, vols. 6-7, 19791980.

51 Garcia Martín, L.: Manual del Guardia Civil, Madrid, 1868, págs. 670-671. 
mozos ni pruebe su ausencia con una causa justa, al que no se presente al Comisionado para ser trasladado a la capital o no se presentase en" la caja de recluta antes de que se marche el Oficial de recepción de los quintos.

Para declarar prófugo a un mozo y hacerle el recargo de servicio respectivo (la pena de servir el doble de tiempo era impuesta habitualmente y en 1800 había sido consagrada por la Ordenanza de ese año), se formará un expediente en el que se hará constar debidamente justificada la no presentación, se pasará el expediente al sindico para que lo formalice en veinticuatro horas, dentro de las cuales se presentará el padre o familiar del presunto prófugo a fin de que exponga las razones de descargo. El Ayuntamiento escuchará las justificaciones orales que se ofrezcan sobre el asunto y declarará o no prófugo al mozo en cuestión en un plazo máximo de cinco días. Si es declarado tal, tendrá que pagar los gastos de su búsqueda y conducción y los daños que se le hayan causado al suplente. Aprehendido o presentado, se le enviará al Cuerpo donde sirve el suplente.

Si el Ayuntamiento no declara prófugo al mozo, enviará un certificado de ello al Consejo provincial, haciéndolo constar por si hay alguna reclamación. El suplente quedará libre en cuanto el prófugo esté aprehendido o presentado; si no tuviese suplente por no haberle tocado ser soldado, se presentará para que sufra el tiempo de recargo en la caja de recluta, si ésta funciona aún, y si no, quedará "a disposición del Capitán General del distrito" ${ }^{52}$. Si el prófugo es presentado por otro mozo comprendido en el alistamiento, el aprehensor quedará liberado de la suerte que le toque en el reemplazo y su suplente podrá ser dado como baja, siempre y cuando en el Ejército no quede una plaza vacante; estas liberaciones quedan invalidadas si el prófugo no es apto para el servicio militar por cualquier causa, pero ello no le exime de pagar los gastos producidos por su fuga y una multa de 5 a 30 duros.

En cuanto a los desertores, la nueva legislación se promulga el 31 de julio de 1866. Su contenido es el más completo y actualizado hasta entonces. Según lo establecido entonces se considera deserción consumada la producida en los siguientes casos:

«Primero. Cuando haya faltado a las dos listas de ordenanza y sea aprehendido después de cuatro días en el pueblo donde se encuentre con su compañía o destacamento, a contar desde la última lista que pasó. 
Segundo. Cuando habiendo faltado a las dos listas de ordenanza fuese preso a menos distancia de cuatro leguas del punto donde se hallaba.

Tercero. Cuando sin faltar a las referidas dos listas, sea preso a cuatro o más leguas de distancia del punto en que desertó.»

Se consideraba conato de deserción (deserción no consumada):

"1.9 Cuando el desertor, sin faltar a las dos listas de ordenanza, sea detenido fuera del pueblo donde se halle de guarnición o destacado a menos distancia de cuatro leguas; o bien dentro del pueblo, disfrazado en ambos casos con ropa de paisano, $u$ otro indicio exterior que manifieste la intención de fugarse, o bien a bordo de embarcación a punto de darse a la vela sin licencia.

2.․․ Faltando a las dos listas de ordenanza, y preso dentro del pueblo antes de los cuatro días."

Igualmente se mantenía la figura de la segunda deserción, que era, lógicamente, la que se cometía después de la primera, al margen de los diversos conatos que entre ambas pudieran producirse protagonizados por un mismo individuo. Serán considerados deserciones en plazas y fortificaciones a menos de seis leguas de las fronteras los siguientes casos:

«1.. Todo individuo que se encuentre disfrazado dentro de una plaza de guerra, punto fortificado, o pueblo donde haya destacamento, sea o no permanente, a menos distancia de seis leguas de la frontera, cometerá el delito de deserción.

2.- Si disfrazado fuese preso a tiro de fusil del último recinto o avanzada, se calificará de deserción consumada.

3.․ Si la prisión tuviese lugar a media legua de los referidos puntos, o a menos de un cuarto de legua de la línea divisoria de ambos países, se declarará consumada la deserción, aunque el desertor vaya sin disfraz.»

También se especificaban las condiciones que debería reunir la deserción en ejércitos en campaña (cuando el detenido fuese en dirección al enemigo o a media legua del campamento hacia retaguardia), condiciones que los generales en jefe podian modificar según estimasen oportuno. "Cuando haya tropa embarcada, con cualquier objeto del servicio que sea, se calificará de conato de deserción el hecho de encontrarse a un individuo disfrazado en el buque. Y si en los propios términos fuese detenido en una lancha para dirigirse a la costa, o bien preso después de haber desembarcado, sea en el puerto, rada o bahía, etc. La deserción en este caso será también consumada. Y lo mismo acontecerá si fuese preso sin disfraz a media legua de los referidos puntos». 
Finalmente se relacionan las "deserciones especiales", deserciones que por el lugar o circunstancias en que se cometían, modificaban la pena ordinaria, y que eran:

«1.. Cuando se cometen en plazas fuertes, puntos fortificados y destacamentos que defienden las fronteras.

2.9 En ejércitos de operaciones o de reserva en campaña.

3. - De centinela o de guardia en tiempo de paz o de guerra.

4. En un buque anclado en puerto, bahía, rada, etc.

5. En la caja de quintas hasta que se incorporan a cuerpo.

6. Hallándose cumplidos.

7.. Perteneciendo al ejército de Ultramar presos en la Península; y viceversa.

\section{8..$^{3}$ Estando indebidamente sirviendo.." ${ }^{53}$}

Como vemos, las disposiciones gubernamentales son bastante minuciosas. Suponen la recopilación de una larga experiencia en la lucha contra la deserción, resultado de las aportaciones de la legislación anterior y la casuística que la práctica ofrece como consecuencia de los procedimientos empleados por los desertores y las sumarias instruidas que muestran las deficiencias de la legislación que ahora se quieren subsanar. La Ley de 1866 será la norma a seguir en el futuro y se tendrá en cuenta para la redacción de la legislación penal militar posterior.

La Ley de 11 de julio de 1885 —que queda muy lejos del marco de nuestro estudio y no abordaremos aquí- se ocupa con más detalle que las anteriores de los prófugos, a los que dedica el capítulo $X$, donde se pormenoriza como nunca hasta entonces en las circunstancias que pueden afectarlos ${ }^{54}$. En cuanto a los desertores, un paso más definitivo se da con la promulgación del Código Penal Militar, aprobado el 17 de noviembre de 1884 y a los que dedica el capítulo $V$ del título IV ${ }^{55}$.

53 El texto de la Real Orden de 31 de julio de 1866 ha sido recogido con reiteración. Nosotros, en aras de la simplificación de las citas, remitiremos al Manual referido, págs. 168 y ss.

54 Ley de reclutamiento y reemplazo del Ejército de 11 de julio de 1885, cap. $X$, arts. 87-101, en Gaceta de 13 de julio y rectificación del 16 de ese mismo mes y año.

55 Martinez Alcublllas, M.: Diccionario de la Administración española, t. II, Madrid, 1886, pág. 633 y ss. El Código en cuestión fue publicado en la Gaceta de 21 de noviembre de 1884 . 


\section{TIPIFICACIÓN Y CARACTERIZACIÓN DE ESTOS DELINCUENTES}

Conducidos los mozos a las cajas de reclutas por los Comisionados de los Ayuntamientos respectivos, se personaban en ellas los Oficiales o Suboficiales receptores de los quintos que se hacian cargo de ellos para conducirlos a sus destinos. A partir de este momento comenzaba su vida militar y serían considerados como desertores si no cumplían su compromiso con el Ejército. También entonces quedaba echada la suerte de los prófugos, que desde ese momento no tendrian paliativos - salvo su espontánea presentación- para mitigar las consecuencias de su incomparecencia.

A veces, por enfermedad $u$ otras causas, algunos quintos no podían incorporarse al mismo tiempo que el resto de sus compañeros, haciéndolo luego por su cuenta, mediante los procedimientos a su alcance, que eran muy diversos. A partir de la creación de la Guardia Civil en 1844, esos mozos serían acompañados en su trayecto por las parejas de este Cuerpo e irian provistos de un pasaporte en el que se expresaba su condición. Sin embargo, en no pocos casos este pasaporte no estaba debidamente redactado y se producía en los guardias civiles la confusión de este cometido con las conducciones de presos, también a cargo de ellos ${ }^{56}$. El Capitán General de Burgos denuncia estas dificultades y pide se especifique claramente en el pasaporte en qué calidad va el conducido por los guardias. La reina Isabel II, en 21 de febrero de 1848, por indicación de su gobierno, determina que figure en dichos salvoconductos, según los casos, la frase «Pasa en calidad de acompañado por los puestos de la Guardia Civil» o "Pasa en libertad acompañado por los puestos de la Guardia Civil», cuando se refiera, en este último caso, a quintos rezagados que no están filiados" ${ }^{57}$.

Además, en tales conducciones se plantearon algunos problemas, bien por falta de claridad en las órdenes recibidas por los guardias, bien por no tener estas órdenes las consiguientes comunicaciones a los Cuerpos donde han de recibir a los quintos, bien por variaciones circunstanciales de las disposiciones generales ya establecidas. Sea como fuere, en ocasiones, si bien no numerosas, los guardias se encuentran con incidentes imprevistos, como el ocurrido en Álava, notificado el 3 de sep-

56 Nos hemos ocupado de este particular en "La conducción de presos en el reinado de Isabel II", en Revista de la Universidad Complutense. Homenaje a $D$. Jesús Pabón (III), 1980.

57 Recopilación..., t. III, págs. 22-23. 
tiembre de 1849: el guardia de caballería Andrés Martínez presentó al Gobernador de Álava trece quintos, seis del Regimiento de Infantería de Gerona y siete del de Bailén; el Gobernador le ordenó llevarlos todos al de Gerona, cuyo Oficial de Guardia sólo quiso hacerse cargo de los que le correspondían; el guardia insistió y fue abofeteado por el Oficial. Cursado el parte correspondiente al gobernador, éste dispuso que los quintos del de Bailén fuesen llevados al Mayor de la plaza y los otros quedasen en su Cuerpo. El hecho provocó una fuerte protesta del Duque de Ahumada, Director General de la Guardia Civil, en defensa de su subordinado ${ }^{58}$. Pero, repetimos, estos casos fueron completamente excepcionales.

Los prófugos se producían, lógicamente, cuando se aproximaba el momento de concentrarse en el pueblo para su presentación en la caja de quintas respectiva; efectuada la presentación, se producen igualmente deserciones, como se comprueba en una circular del Duque de Ahumada dirigida a los Jefes de los Tercios de la Guardia Civil cuando se aproximaba el reemplazo de 1845: "Acercándose el momento en que los quintos del año 1845 deben tener entrada en las Cajas..., en cuya época siempre se ha cometido considerable número de deserciones" ${ }^{99}$.

Desde el momento en que empezaban los trámites del reclutamiento hasta habituarse a la vida militar, los mozos vivian uno de los períodos más críticos de su vida. Suponía para la mayoría de ellos, gentes sencillas, apegadas al terruño, la ruptura de todos los lazos con su vida familiar y su modo de vida cotidiano para iniciar una experiencia vital en la que todo les era nuevo, incluso el mismo escenario geográfico. Por otro lado, la adaptación al nuevo régimen de vida no era fácil; los más decididos -o los menos animosos, según se considere- se convertían en prófugos, mientras que otros que se decidían por sentar plaza y se incorporaban a sus Cuerpos, sufrían una auténtica prueba en los primeros meses de vida militar, prueba que empujaba a cierto número de ellos a la deserción ${ }^{60}$.

Los que abandonaban delictivamente la milicia, a veces eran veteranos, pero el gran porcentaje lo dan los reclutas, que no acaban de

${ }^{58}$ Recopilación..., t. IV, págs. 128-129. Mantendremos la referencia a la Recopilación para una mayor comodidad tanto del autor como del lector que desee verificar alguna comprobación. En la Gaceta las órdenes aparecen con unas fechas de retraso respecto a la que lleva el escrito, fecha que también recogemos para facilitar la búsqueda del que prefiera recurrir a esta fuente.

435.

${ }_{59}$ Circular de 12 de noviembre de 1846; vid. Recopilación..., t. I, págs. 434 -

${ }^{\infty}$ El mismo Ahumada lo dice en la circular recogida en la nota anterior. 
encajar en el ejército. Entre éstos se contaban por igual los incorporados forzosamente $y$ los sustitutos de aquellos más afortunados o adinerados que pudieron comprar su exención. Los sustitutos desertaban por razones similares a las de los mozos que cubrian su propia plaza y porque la responsabilidad de su falta no iba exclusivamente contra ellos, pues los sustituidos durante un tiempo - generalmente, un añoquedaban como garantes de sus sustitutos, de modo que si éstos desertaban, aquéllos ocuparían inmediatamente su plaza. En tal sentido no se admiten paliativos. Buen ejemplo es una real orden isabelina que, de acuerdo con el dictamen del Tribunal Supremo de Guerra y Marina, encarga a los Inspectores de las armas del ejército que no dejen pasar ni siquiera veinticuatro horas sin reclamar a los quintos sustituidos cuando sus sustitutos hayan desertado dentro del año de su responsabilidad, decisión que se toma por haberse planteado numerosos casos de este tipo, lo que demuestra, por una parte, la reiteración del delito $y$, por otra, la incapacidad de los gobiernos para impedirlo, puesto que han de recurrir a la amenaza de los sustituidos para lograr una garantía de eficacia ${ }^{61}$.

El desertor huye siempre a descampado y en él vaga unos días, alejándose de todo núcleo habitado para buscar trabajo o subsistir, ocupándose en algún caserío o rincón olvidado de todos. Sería interesante ver la conexión que pudiera existir entre desertores y bandidos, así como el grado de importancia que tuviese. Hay que pensar que su acción era una ruptura con la sociedad, lo que les empujaría a cualquier acto, y entrar en contacto con los bandidos, abundantes entonces, sería una de las soluciones más asequibles para ellos, pasando así a formar parte de las cuadrillas de bandoleros de forma ocasional, pero después, acostumbrados a este género de vida y ante las dificultades para abandonarlo, acabarían como auténticos bandidos. No olvidemos que este tipo arriesgado de vida tiene mucha garra y prende en el hombre con cierta facilidad por la afirmación de individualidad e independencia que supone en todos los órdenes. Recordemos que algunos guerrilleros de la Guerra de la Independencia acabaron sus días como auténticos bandidos ante la dificultad de adaptarse a un nuevo régimen de vida una vez terminada la contienda. Cuando el desertor conseguía pasar un tiempo sin ser descubierto, se atrevía a vivir en las ciudades, donde la abundancia de personas le aseguraba el anonimato y en ella podía desenvolverse tranquilamente, dándose casos en verdad sorprendentes, como la captura de "un desertor, en 1856, del ejército perteneciente al reemplażo de 1834, al cual después de haber estado emigrado en Francia algunos años, y en más de doce

81 Decreto del Ministerio de la Guerra de 17 de septiembre de 1845; Recopilación..., t. l, págs. 81-83. 
que se hallaba en el país no le había molestado ninguna autoridad por tal delito" ${ }^{22}$. También hay casos que nos sorprenden de desertores que se convierten en bandidos, como el siguiente, que nos confirma en la idea de que desertor y bandido corrían muy cerca, pues son frecuentes casos como éste: «Fue aprehendido un desertor de las Torres de Cuarte de la ciudad de Valencia, el cual desde su fuga andaba cometiendo toda clase de raterías y delitos, teniendo amedrentados a los buenos habitantes del pais que con su captura han recobrado la tranquilidad que tenian perdida con la existencia de aquel malhechor" ${ }^{63}$.

Los datos sobre desertores que aparecen en las publicaciones de régimen interno y en los periódicos de la Guardia Civil nos permiten deducir el comportamiento de estos hombres. En numerosas ocasiones, las circulares del Cuerpo insisten sobre la prestación de tal servicio; así la del 20 de febrero de 1847, en la que se notifica: "La aprehensión y continua persecución de prófugos y desertores, debe ser una de las más constantes atenciones de la Guardia Civil por ser uno de los servicios de más consecuencia para la tranquilidad y seguridad del país" ${ }^{64}$, o como la de 4 de julio de 1857, que encarga se persiga sin tregua ni descanso a los desertores y prófugos ${ }^{65}$.

En función de esta obligación, la documentación de la Guardia Civil nos suministra abundantes referencias a tales delincuentes que nos permiten conocer su comportamiento al margen de la ley. Con las circulares, la Superioridad de la Institución pretende adiestrar a sus subordinados para este servicio y su contenido va a ser incorporado a la Cartilla del Guardia Civil, especie de memento de las obligaciones del guardia que procura cubrir toda la casuística de los servicios que presta la Institución. En ella hay un apartado dedicado a prófugos $y$ desertores, del que entresacamos lo que ahora nos interesa. Por lo pronto se advierte que "los que cometen el delito de deserción por lo general se van a la inmediación de sus familias donde pueden encontrar más protección; los prófugos por el contrario varian por lo común de residencia". Así pues, tenemos una clara diferencia en el comportamiento de ambos tipos de delincuentes, diferencia que viene impuesta por las características del reclutamiento al cubrir las plazas de los prófugos con mozos que no entraban en el cupo y al permitir al captor de los prófugos ventajas que iban, según las épocas, desde la inmediata liberación del servicio de aquel que ingresó para cubrir la plaza del que no compareció al llamamiento a filas hasta la exención del servicio.

62 Mentor del Guardia Civil, 1 de julio de 1856.

63 Mentor..., 16 de enero de 1857.

4 Recopilación..., t. II, Madrid, 1847, págs. 142-143.

65 Recopilación..., t. VII, pág. 167. 
Por eso, el prófugo no se atrevía a volver a su lugar de origen, pues la familia del joven que ocupó su lugar en filas estaba especialmente interesada en su captura y como además alli le conocian todos, podia ser denunciado o detenido por alguien interesado en librarse a sí mismo o a algún familiar de servir en el ejército. Cosa que no ocurría con el desertor, ya que éste con su acción no perjudicaba a un tercero.

Por otra parte, estos delincuentes procuraban cambiar su aspecto a fin de no poder ser identificados. "Todo prófugo y desertor lo primero que procura es disfrazarse, y estas circunstancias deberá tenerlas muy presentes el Guardia Civil para examinar detenidamente a los transeúntes que por sus trajes y especialmente por el desaliño en el modo de llevar alguna prenda militar, o por sus señas personales, pueden inducir sospechas de que se halla en uno u otro caso". Y en función de esta realidad, se recomienda reconocer "con mucha escrupulosidad los documentos de que vayan provistos los viajeros que encuentre, que por su traje parezcan pordioseros o mendigos, porque los criminales fugitivos se aprovechan de este disfraz muchas veces para eludir la persecución que se les hace». Se añade a continuación: "Asimismo reconocerá y examinará con el mayor cuidado los documentos de aquellos que por su traje y porte infundan sospecha, y particularmente si fuesen a caballo o con armas". Y hay más todavía, pues las licencias absolutas podían ser falsas y de este modo moverse dentro de una aparente legalidad en los primeros momentos de la deserción; lo mismo cabe decir de las licencias temporales, por eso se hace especial hincapié en su reconocimiento: "La licencia absoluta o temporal de todo soldado que marcha solo por los caminos o llegue a las poblaciones, debe también examinarla con mucha atención y cuidado el Guardia Civil por si fuese falsa" ${ }^{66}$.

Una prueba de que con frecuencia se volvia sobre este tema dentro de la Institución de seguridad aludida es el párrafo siguiente, que nos ofrece nuevos detalles de las artimañas de prófugos y desertores: "De ordinario todo el que se fuga procura disfrazarse, ya cambiando de traje, afeitándose el bigote o patillas, si las tenía, o poniéndose un pañuelo por la cara como si tuviera algún mal de oídos" ${ }^{67}$.

El valor de estos párrafos es grande, pues nos descubre los procedimientos usuales en prófugos y desertores para evitar su detención. Su

66 Cartilla del Guardia Civil, Madrid, 1852, págs. 33-34. La primera edición de la Cartilla fue muy temprana, pero la más lograda es la de este año, que se reedita durante lustros apenas sin modificaciones. En 1989 el Ministerio del Interior ha lanzado una edición facsímil realmente encomiable.

B7 García Martín, op. cit., pág. 671. 
primer cuidado es variar su aspecto físico para que las señas que figuran en los partes de deserción y requisitorias no coincidan con las que en ese momento presentan y para modificar su apariencia todos los procedimientos son buenos, pero los resultados no siempre eran satisfactorios, pues su escasez de medios económicos les impone el seguir usando prendas militares que podian delatarles, al tiempo que no se deshacen de las armas con las que hayan podido fugarse para usarlas en su defensa o venderlas.

También es posible deducir de tales instrucciones que los momentos más propicios para capturar a los prófugos $y$, más especialmente, a los desertores eran los días inmediatos a aquel en que se descubra su falta. En efecto, en ambos casos han de huir y la huida impone un desplazamiento por un medio geográfico, prácticamente, desconocido, por lo que es casi imprescindible no apartarse de los caminos, otro inconveniente para ellos al facilitar su localización.

Superados estos primeros días, el prófugo o desertor tenía más posibilidades de salir adelante en su empeño, máxime si lograba un trabajo u ocupación estable en un lugar apartado. Normalizar su vida y crearse unas relaciones y amistades podían ser la garantía de su impunidad. Ya hemos señalado la conexión de los desertores con los bandoleros; en estos casos, sólo después de su detención o muerte se descubria la condición de desertor, al poder comprobar su personalidad de modo fidedigno.

Por lo demás, creemos que todas estas apreciaciones, válidas para la España de la Constitución de 1845, pueden aplicarse por igual a períodos anteriores y posteriores. La persistencia de determinadas realidades en el reclutamiento (fianzas, exenciones, sustituciones...) entraña mecanismos de respuesta similares en su funcionamiento. Es posible que existan algunas diferencias entre las primeras décadas del siglo y las últimas, pero por la persistencia de las referidas realidades pensamos que a lo largo del siglo XIX tanto el prófugo como el desertor recurrirá a disfraces, y mientras aquél tendría que apartarse de su familia, éste encontraria en los suyos un abrigo más seguro.

\section{NOTIFICACIONES OFICIALES DE LA EXISTENCIA DE DESERTORES Y PRÓFUGOS}

Confirmada la condición de prófugo de un mozo y de desertor de un soldado, se procedía a dar parte de la falta $y$ del autor para que se iniciara su búsqueda y captura. Como las consecuencias de estas faltas eran distintas para el ejército, toda vez que la plaza del prófugo la ocupaba otro mo- 
zo, cosa que no ocurria con el desertor, habrá un procedimiento distinto en la persecución de ambos delincuentes. En efecto, al analizar la documentación a ellos relativa se comprueba que la notificación de la existencia de prófugos y la canalización de las gestiones de su búsqueda dependen de los Justicias de los pueblos, mientras que la persecución de los desertores estaba respaldada por todo el aparato militar del país, por ello se encuentra más reglamentada y es más clara la pretensión de eficacia, cosa lógica si pensamos que el prófugo sólo va a dejar en entredicho una autoridad meramente local, mientras que el desertor atenta directamente contra la esencia de una institución vertebral del Estado, por lo que su impunidad tendría unas funestas consecuencias, mucho más perniciosas que las del prófugo. Había cuestiones de alto prestigio involucradas con la deserción: si los militares salían de sus cuarteles para desde el gobierno poner orden en la familia civil, ¿qué pensaria éste si no eran capaces de mantener $y$ hacer cumplir la ley dentro de su propio ejército? Además, si el desertor salía adelante en su empeño, tendría que vivir marginado al orden establecido, seria un fuera de la ley con la posibilidad de que protagonizase una vida delictiva, de que fuera una amenaza, en suma, para la sociedad, con lo que se convertía en un doble peligro al personificar la contestación del orden militar y la amenaza para el orden social.

Con los prófugos no ocurria lo mismo, y su captura, en principio al menos, parece más fácil. No podian quedarse en las inmediaciones de los suyos por temor a los vecinos que los delatarían animados por las ventajas que obtendrían de su delación. En consecuencia, tenian que cambiar de ambiente $y$ buscar asentamiento en medios geográficos y humanos desconocidos, en los que que sólo a base de una gran discreción podían lograr un cierto grado de seguridad. Además, los prófugos eran muchachos jóvenes, por lo que su edad se convertía en uno de los mayores obstáculos de los muchos que debían afrontar, pues no dejaria de llamar la atención la llegada a un lugar de un mozo desconocido en edad de servir en el ejército. El desertor, por el contrario, al contar con la protección de la familia y no perjudicar a ningún convecino, estaba al margen de tales dificultades. Por ello, pensamos que la detención de un prófugo era más fácil que la de un desertor. Esto y las mayores implicaciones de la deserción pueden explicar el diverso tratamiento que se da a ambas faltas y que en la documentación tenga más eco la segunda.

A lo largo de todo el período que nos ocupa, incluso antes y después, la calificación de prófugo la emitían los Justicias de los pueblos y a ellos correspondia dar los avisos pertinentes para su captura ${ }^{68}$. En cuan-

68 Véase por ejemplo la Real Ordenanza en que S.M. establece las reglas que invariablemente deben observarse para el reemplazo del Exército, Madrid, 
to a la deserción, los Cuerpos daban cuenta de las que se producían en sus efectivos y entraban en contacto con las autoridades civiles para aprehender a los que abandonaban las armas, pero hasta la aparición de la Guardia Civil no se va a contar con un instrumento adecuado para llevar a cabo estas persecuciones, cuyos resultados son mayores que los obtenidos hasta entonces. Será a partir de 1844, por tanto, cuando la persecución de la deserción empiece a adquirir su forma más lograda y cuando la localización de los prófugos desborde el carácter local y civil que hasta entonces había tenido. Ya hemos visto cómo se encarga a este Cuerpo la detención de tales tipos de delincuentes, por eso no insistiremos. Sí señalaremos que al hilo de la persecución de los desertores se le encargará la de los prófugos, delincuentes también que a su no comparecencia a filas podían sumar una vida delictiva "activa", semejante a la de los malhechores o bandoleros. Como la acción contra los prófugos mantiene siempre ese carácter local y civil a que antes aludíamos y la legislación referente a ellos mantiene unos principios muy estables, nos ocuparemos preferentemente de la de los desertores, más profusa y $\mathrm{mi}$ nuciosa, que en el reinado de Isabel II adquiere sus rasgos más perdurables y en ello es decisiva la creación de la Guardia Civil. En este orden de cosas, el período de vigencia de la Constitución de 1845 resulta decisivo.

Y así, "para que los buenos efectos que en la persecución y aprehensión de desertores ha producido el establecimiento de la Guardia Civil sean más eficaces y prontos", la Reina ordena en 11 de junio de 1845, a través del Ministerio de la Guerra, que los Jefes de los cuerpos, tan pronto tengan noticias de alguna deserción, pasen una comunicación a la Guardia Civil de la provincia para que, insertándose en el Boletín Oficial, llegue a noticia de la misma. Estas prevenciones las tendrán presentes todos los Jefes de partidas o destacamentos y las cumplirán independientemente del parte que han de cursar a sus superiores. Por otra parte, los comandantes generales de provincia, el mismo día de este decreto, reciben orden de pasar a la Guardia Civil los mismos datos de los desertores que tienen las cajas de quintas y los depósitos y de cuantos «individuos sueltos" haya en la provincia ${ }^{69}$.

Desde el 1 de abril de 1845 estaba ordenado que los comandantes de puesto de dicha institución anotasen en los diarios de servicios los regimientos a que pertenecen los desertores detenidos ${ }^{70}$, pero como no se

1800, págs. 97 y ss., y la Ley de reclutamiento y reemplazo del Ejército de 11 de julio de 1885 , cap. $X$, arts. 90 y ss.

${ }_{69}$ Recopilación..., t. l, pág. 65.

$70 \quad$ lbidem, pág. 323. 
hizo mucho caso de ello, en 25 de octubre de 1847 se vuelve a insistir sobre el mismo punto y se recomienda se tenga muy presente al redactar los citados diarios ${ }^{7}$. Para ejercer un mayor control sobre los desertores se dictamina, según la Orden de 3 de agosto de 1849; que cuando ocurra una deserción en cualquier cuerpo del ejército, el jefe del mismo mandará media filiación al comandante de la Guardia Civil del punto donde se produjo la deserción y también al comandante de la provincia a la que corresponde el pueblo de donde es natural el desertor ${ }^{72}$, pues, como sabemos, los desertores buscaban la proximidad de su familia. En este sentido abunda la Orden de 31 de julio de 1851, al estipular que en las requisitorias que se dirijan a la Guardia Civil se hará constar los nombres, apellidos y apodos de las personas que se buscan, así como los de sus padres, lugar de nacimiento, sitio donde residió en sus dos últimas estancias, con el Ayuntamiento, provincia y juzgado a que pertenecen dichos lugares $y$, finalmente, las señas personales del sujeto buscado para evitar confusiones entorpecedoras ${ }^{73}$.

Las revueltas de 1856 influyen muy directamente sobre el abandono de filas, hasta el punto de que el Ministerio de la Guerra tiene que dar una orden concreta, independiente de las numerosas que hay sobre el tema, orden que comunica el Duque de Ahumada a sus subordinados el 3 de noviembre de ese año, instándoles a que consigan el mayor número posible de capturas, "en inteligencia de que éstas servirán de especial recomendación para los que las logran"; les notifica que los datos de los desertores los recibirán en las cajas y que den parte cada ocho días hasta que todos los huidos de la provincia estén apresados ${ }^{74}$.

Para llevar el mejor control, el Inspector general de la Guardia Civil ordena el 30 de diciembre de 1851 que con el diario de servicios de la cuarta semana de cada mes se envíe la relación de todos los desertores aprehendidos. Con dichas relaciones se confeccionan las listas numéricas mensuales específicas de ambos delitos en cada provincia, las que a su vez componen la relación anual de aprehensiones por Tercios y provincias que son dadas a la luz pública y en la que nosotros no nos detendremos $^{75}$.

"Recopilación..., t. II, pág. 200.

72 Recopilación..., t. III, pág. 120.

73 Recopilación..., t. V, págs. 85-86.

74 Recopilación..., t. VII, págs. 183-184.

75 Dichas relaciones constituyen un conjunto de datos muy interesantes que permiten reconstruir la cadencia temporal y la incidencia geográfica de la deserción. De la misma forma, listas semejantes sobre los prófugos permiten un tratamiento similar. En breve daremos a conocer un estudio sobre ambas figuras delictivas que tienen en estas fuentes su principal soporte. 
Paralelamente a estas órdenes, aparecieron otras en el ejército con objeto de que las jerarquías correspondientes tomaran las medidas más apropiadas a fin de obtener los mejores resultados en la detención de los desertores. Tales disposiciones fueron incorporadas a la Ordenanza del Ejército vigente en la parte final del reinado de Isabel II. En ella se recomienda que las justicias de las guarniciones, cuarteles y tránsitos notifiquen las deserciones mediante requisitorias a los justicias de los lugares inmediatos, incluyendo la filiación del desertor y la enumeración de las prendas de vestuario con las que se fugó, y las justicias receptoras de estas requisitorias enviarán copia "a las de los demás pueblos, siguiendo asi de unos a otros con dirección por los caminos transitables que vía recta se dirijan a fronteras, puertos u otros pasos precisos". Pero si la captura de los desertores no se logra con prontitud, los coroneles o comandantes de los regimientos darán aviso al comandante general del reino o provincia donde la deserción se consumó y también al del distrito de donde es natural el desertor, quienes a su vez se advertirán, incluyendo copia de la filiación, "a los corregidores de los partidos respectivos para que éstos comuniquen sus órdenes al lugar de naturaleza del desertor y a los demás que convenga a efecto de perseguirle y aprehenderle, y cada uno de los corregidores acusará al capitán general el recibo de su orden y de la que ha comunicado a las justicias, y al fin de mes les dará cuenta de los resultados; anotándolo todo en un libro de asiento en la secretaría de la capitanía general y otro en la de cada corregidor, remitiendo éste cada seis meses relación y estado de su libro al capitán general para confrontarle con el de su secretaría y verificar si ha habido o no omisión". Hasta aquí el contenido de los dos primeros artículos ${ }^{76}$.

El del tercero merece la pena recogerlo literalmente en su totalidad: "Para que todos vivan entendidos de la obligación que tienen de descubrir y asegurar los desertores y de las penas en que incurran los que no lo ejecutaren, mando a todos los corregidores que en las capitales donde residen y en los pueblos de su distrito hagan publicar bandos y fijar edictos, en que se exprese que los individuos que tuviesen noticia de los desertores y no los delatasen a la justicia, por el mismo hecho... quedarán obligados a satisfacer al regimiento, doce pesos de a 15 reales de vellón para reemplazar otro soldado, y asimismo el importe de las prendas de vestuario y menajes que se llevó, y a más las gratificaciones a los que denunciaren y aprehendieren los tales desertores disimulados o no denunciados, con todos los gastos de su custodia y conducción; y en la misma pena incurrirán las justicias que resultaren omisas en estas diligencias; con advertencia que si el que incurriere en esta inobservancia no tuviese caudal con que satisfacer, siendo plebeyo se aplicará al 
servicio en lugar del desertor en su propio regimiento, por el tiempo que éste debía servir, como no sea menos de cuatro años, y al noble se destinará por el mismo tiempo a uno de los presidios. $Y$ en el caso de que las justicias o particulares ocultasen o auxiliasen a los desertores dándoles ropa para su disfraz, o comprándoles algunas prendas de su vestuario o armamento, además de la obligación de reemplazar de todo al regimiento, se aplicará al plebeyo a seis años de servicio en los arsenales $u$ obras públicas, y al noble a seis de presidio. Si fuesen mujeres se les precisará a volver las alhajas, y multará en 20 ducados, depositándose este producto para los gastos; y si fueren eclesiásticos los que diesen este auxilio, con la información del nudo hecho, remitirán las justicias las diligencias practicadas al corregidor del partido, y éste al capitán general de la provincia, para que la pase a mi noticia, por medio de mi secretario del despacho de guerras" ${ }^{77}$.

La cita ha sido larga, pero hemos preferido incluirla íntegra por ser el texto más completo y extenso de los que hemos consultado relativos a las penas que recaerán sobre cuantos de alguna forma ayuden o encubran a los desertores. Con lo expuesto hasta aquí, el dispositivo anti-deserción quedaba perfilado y en los años siguientes hubo escasas alteraciones. La cadena que transmitiría la notificación de las deserciones y la captura de los desertores quedaba trazada con toda nitidez.

Observando los datos que sobre detenciones tenemos en los años en que nos hemos centrado ${ }^{78}$, probablemente no encontremos una relación causa-efecto entre estas medidas y las detenciones habidas, mecanismo que influiria de modo decisivo en la deserción, pues si la acción de las fuerzas de Seguridad o de los agentes del orden se mostraba eficaz, los soldados tentados por la idea de desertar se pensarían mucho llegar a intentarlo, ya que sobre ellos actuaría la imagen de una pronta e irremisible captura y el endurecimiento de su suerte al recibir las sentencias condenatorias que recaian sobre la falta cometida.

77 Recomendamos la consulta de esta Ordenanza en la obra de Garcia MARTín, ya citada, porque abundan en ella las referencias a las reales órdenes que van informando su contenido; la parte relativa a las deserciones figura en el título XII, "Reglas que deben observarse para la persecución y aprehensión de desertores, y obligación de las justicias para su descubrimiento y conducción», págs. 163 y ss.

78 En ese estudio a que nos referíamos en la nota 75, trataremos de esclarecer cuáles fueron los factores y las circunstancias que dejaron sentir su incidencia en el ritmo de aparición de desertores y prófugos, así como la cadencia de los resultados obtenidos en su aprehensión, lo que aspiramos a hacer geográfica $y$ cronológicamente, para comprobar si los distintos ritmos provinciales son similares o difieren entre sí. 
En cambio, parece que no podemos dudar de que por entonces se conseguía un granado engranaje que coordinaba los esfuerzos de las distintas autoridades, coordinación tendente a evitar los efectos negativos que se derivaban de la impunidad en que pudieran quedar los prófugos y los desertores. Además, nada tiene de extraño que la pieza clave en ese engranaje fuera la Guardia Civil, la principal institución de seguridad existente entonces, creada un año antes de que apareciera la Constitución de 1845 y con una cobertura territorial de alcance nacional facilitadora de su acción en este orden de cosas.

\section{MEDIDAS GUBERNATIVAS ANTE LOS DELITOS MILITARES}

Los diversos gobiernos españoles, a lo largo del siglo XIX, utilizarán dos procedimientos principalmente para acabar con los delitos militares. Uno es la concesión de gracias, indultos o amnistías, concesiones que afectaban a prófugos y desertores. El otro consiste en la reglamentación de las penas con que se han de castigar estas faltas y que sufren variaciones a lo largo del siglo que nos ocupa. El balance que arrojan los resultados obtenidos con ambos procedimientos no es alentador. $\mathrm{Ni}$ el perdón ni el castigo fueron frenos auténticos para desertores y prófugos.

En cuanto al primero de los procedimientos señalados, hay que hacer constar su carácter ocasional y también su ineficacia, como demuestra su empleo frecuente. Es cierto que no poseemos las relaciones de los acogidos a los sucesivos indultos, ya que entre la documentación que hemos utilizado no aparece la más leve referencia a esta cuestión de un modo directo y con cifras demostrativas. Ni los gobiernos ni las autoridades especificamente militares se detienen en este punto, lo que nos hace pensar que la incidencia de estas iniciativas fue escasa, los resultados desalentadores y todo quedó reducido a las respectivas notas en las filiaciones y hojas de servicios. Además, la abundante concesión de perdones por los más diversos motivos nos habla de la pervivencia de los males que se querían atajar.

Por lo que respecta al segundo procedimiento, tiene un carácter más fijo, se incluye en la legislación militar y es el procedimiento ordinario para acabar con prófugos y desertores. Las medidas contra estos delincuentes, especialmente contra los desertores, menudean a lo largo del siglo XIX, pero entre ellas destacan unos textos que son el resultado de iniciativas anteriores, por lo que podemos considerarlos como el final de un proceso y cuya aparición jalona muy claramente el ochocientos español. 
Según deciamos, no tenemos resultados de las iniciativas emprendidas dentro del primer procedimiento que hemos señalado. Por ello, creemos que seria superfluo recoger aquí todas las concesiones de esta índole. En consecuencia, y con una finalidad meramente indicativa, nos limitaremos a señalar las habidas en tiempos de Isabel II, magnífico exponente de la reiteración gubernamental en el uso de un procedimiento circunstancial y extraordinario que por su frecuencia se convierte casi en habitual y ordinario, de manera que estos delincuentes, de haberlo querido, podían haber actuado con la certeza de que un perdón extraordinario podía redimirles su culpa y reintegrarles al ejército, y es precisamente en este punto, su vuelta a la milicia, donde estaba, a nuestro juicio, la razón del "fracaso" en el procedimiento del perdón, ya que acogerse a él significaba volver a la situación anterior a la perpetración del delito y no la desaparición de los motivos que empujaron a delinquir. Veamos cuáles fueron las gracias más significativas concedidas en el reinado de Isabel II desde 1846 a 1867, años que coinciden, prácticamente, con los de vigencia de la Constitución de 1845.

El matrimonio de la reina y de su hermana será causa de que se repartan gracias por toda la Península: perdones generales para delitos leves, amnistías políticas, ascensos a las clases militares, etc. Entre estas gracias no podían faltar las destinadas a los prófugos y desertores y en general a todos los reos de la jurisdicción militar. Se hallan contenidas en un indulto, cuyos artículos fundamentales son los siguientes:

«Art. 4.9 Los Sargentos, Cabos, Soldados y gentes de mar que hubiesen incurrido en el delito de deserción y se acojan a este indulto gozarán de sus beneficios, quedando los Sargentos y Cabos privados del empleo que abandonaren y obligados a servir el tiempo que les restaba cuando desertaron, aunque con opción a los premios a que se hagan acreedores por servicios que presten después de la aplicación de la Real Gracia.

Art. 5. Los Capitanes y Comandantes generales de las Provincias y Departamentos destinarán a los Sargentos, Cabos y Soldados que se les presenten acogiéndose a esta gracia a sus propias compañias y sin excepción de Cuerpos; y cuando éstas no estuviesen en la demarcación del mando de dichas autoridades, lo verificarán al que tengan por conveniente, siendo de su propia arma...

Art. 7.- Será extensivo este indulto a los reos ausentes o rebeldes de delitos no exceptuados que se presenten, o sean aprehendidos en el término de tres meses, si se hallan en la Península o islas adyacentes; de seis si estuviesen en las Américas o país extranjero, $y$ de un año si se hallaren en los dominios de Asia, contados desde el día de la publicación del indulto; y luego que en uno u otro caso estén a disposición de cualquier autoridad militar o civil, darán éstas inmediatamente cuenta al Jefe superior Militar de la provincia... 
Art. 15. Los indicados Jefes superiores remitirán al Tribunal Supremo de Guerra y Marina listas nominales de los indultados, con expresión de las clases de delitos." ${ }^{79}$

En las provincias se crearian unos depósitos para recibir a los desertores, a quienes se destinaría de acuerdo con los siguientes términos: a los que han cumplido ya el plazo de su servicio en el ejército se les concederá licencia absoluta, y entre ellos los que tengan derecho a retiro serán propuestos para que lo reciban; los que tengan que cumplir aún el tiempo de su empeño serán distribuidos entre los cuerpos del ejército, recomendándose a los oficiales y jefes los vigilen especialmente, a fin de ver su comportamiento. El envio de las relaciones nominales de estos individuos ha de hacerse rápidamente para que el destino de los acogidos a indulto se fije con urgencia y los depósitos puedan disolverse sin demoras $^{80}$.

Se esperaban grandes resultados de este indulto, pero la realidad fue otra, pues los más prefirieron seguir marginados - tal vez por falta de confianza en la sinceridad de la concesión-y tampoco sirvió para atajar el mal, como lo prueba el índice de capturas verificadas en ese año y en los siguientes. Como el objetivo del indulto era hacer desaparecer a los desertores, su contenido era bastante amplio y se les daban todo tipo de facilidades. El 24 de noviembre de ese mismo año de 1846, el Auditor de Guerra de la Capitanía General de Castilla la Nueva pregunta si los desertores por segunda vez gozan de la gracia contenida en el indulto, pues el artículo 2. ${ }^{\circ}$ de dicho indulto excluye a los reincidentes. La contestación le llega tres días más tarde para confirmarle que sí están comprendidos, con lo que la línea de concesiones se amplía aún más ${ }^{81}$, pero no por ello mejoraron los resultados.

El año 1849 fue también prolífero en concesiones gubernamentales, si bien los desertores no están muy afectados por ellas ${ }^{82}$. Los prófugos se habían visto el 24 de abril favorecidos con un indulto que les relevaba de la pena de servir en Ultramar, pero seguian con la obligación de reintegrar los socorros que hubiesen recibido de la Compañia de depósito, donde eran reunidos ${ }^{83}$.

\section{I, págs. 179-183.}

79 El indulto se promulga en 30 de octubre de 1846. Vid. Recopilación..., t.

80 Real Decreto del Ministerio de la Guerra de 11 de noviembre de 1846; vid. Recopilación..., t. I, págs. 186-187.

${ }^{81}$ Recopilación..., t. l, pág. 188.

${ }_{82}$ Recopilación..., t. IV, págs. 108-109; amnistia, págs. 94-97.

*3 Ibidem, pág. 58. 
Los desertores normalmente eran destinados al regimiento fijo de Ceuta. En este año de 1849, en 8 de septiembre, sale una orden del Ministerio de la Guerra en la que se comunica a los Directores e Inspectores Generales que no se destinen más amnistiados a este regimiento, que los que se presenten en adelante se los repartan los Cuerpos de que proceden ${ }^{84}$. En 31 de diciembre de 1852 se hace público que son muchas las instancias que se presentan para pedir indultos de desertores, sin que se presenten éstos, lo que es contrario al tenor de la Orden de 15 de julio de 1845. A fin de cortar esta anomalía se ordena que no se curse ninguna instancia de desertores que no se hayan presentado.Tal procedimiento nos muestra las reticencias existentes entre los interesados, como antes señalábamos que preferían no entregarse hasta no tener la certeza de su perdón y la garantía de no comparecer ante un consejo de guerra $^{85}$.

Un nuevo indulto se promulga el 11 de agosto de 1854; antes, en 1853, y después, en 1857, también registramos medidas suavizadoras sobre el particular, pero sin alcanzar nunca el resultado que el gobierno esperaba ${ }^{86}$. Especialmente significativo es el perdón concedido en 26 de diciembre de 1857 con motivo del nacimiento del futuro Alfonso XII. En él se dice que se rebaja la quinta parte de la condena a los reos sentenciados a cadena, reclusión, relegación y extrañamiento temporales; la cuarta parte a los sentenciados a presidio, prisión y confinamientos mayores; la tercera a los sentenciados a presidio, prisión correccional y destierro. Los sentenciados - sigue el indulto- a arresto mayor o menor, prisión o campaña extraordinaria por seis meses o menos, o bien a prisión correccional por vía de sustitución o apremio, serán puestos en libertad. Para la aplicación de estas gracias es preciso que los sentenciados estén cumpliendo su condena, y si alguno por acogerse a estas rebajas termina antes su servicio que los reclutas de su quinta se le destinará al Fijo de Ceuta hasta extinguir el tiempo de su empeño. Se consideran comprendidos en este indulto a los sargentos, cabos, soldados y gentes de mar sentenciados, castigados o pendientes por deserción consumada antes del 7 de diciembre de este año. Para los prófugos, los encausados por conato de deserción y deserción de primera vez sólo se alzan los recargos y quedan en sus Cuerpos como soldados normales para cumplir el tiempo que les falte de empeño con todos los derechos y deberes; los sargentos y cabos en estas circunstancias no recobrarán su grado. Por último, tales gracias son aplicables siempre que se presenten los reos militares antes de los cuatro meses en la Pe-

${ }^{84}$ Ibidem, págs. 130-131.

${ }_{85}$ Recopilación..., t. V, págs. 70-71.

86 Véase como ejemplo, Recopilación..., t. XII, Madrid, 1857, págs. 50-51. 
nínsula o islas próximas ${ }^{87}$. Dos años más tarde, en 26 de abril de 1859, se promulga un indulto en favor de los que desertaron al extranjero ${ }^{88}$.

Como vemos, todas estas amnistías y perdones pretendían resolver un problema permanente en el ejército, pero lo único que consiguieron fue paliarlo en una circunstancia concreta y precisa. Lo único que varía es su periodicidad y cuantía en relación con situaciones sociales, pues en su entraña es un problema social. Por tanto, estas medidas y las similares anteriores y posteriores no eran sino soluciones de circunstancias. Era preciso que cada delito estuviese perfectamente reglamentado, con unas penas concretas para cada caso y con la consideración de atenuantes y agravantes, reglamentación que marcaría el camino a seguir en todo momento y en cada circunstancia. Como ya hemos visto, las penalizaciones relativas a prófugos, poco numerosas y contenidas en sus directrices fundamentales en las Ordenanzas de 1800 y 1837 y en la Ley de $1885^{89}$, nos ocuparemos ahora de las sanciones impuestas a la deserción, cuya reglamentación es más profusa y sufre matizaciones frecuentes.

El primer texto legal que nos interesa es el promulgado por Fernando VII en 8 de enero de 1815, en el que restaura penas generales del ejército vigentes a finales del siglo XVIII ${ }^{90}$. Consta de ocho artículos y en síntesis dice así: Los desertores en campaña, si se pasan al enemigo y son apresados, serán ahorcados. Los desertores que abandonen el ejército huyendo. a retaguardia sufrirán "seis carreras de baquetas por doscientos hombres y diez años de galeras». Los que deserten en puntos que dependan del ejército en campaña soportarán cuatro carreras de baquetas por doscientos hombres y cuatro años de arsenales. Los desertores de un puesto sin dependencia del ejército en campaña tendrán seis años de arsenales. El desertor de infanteria de primera vez sin circunstancias agravantes en España e Indias tendrán cuatro meses de prisión y ocho de servicio en su propio Cuerpo, contados desde el día de aprehensión (RR.OO. de 11 de junio y 1 de julio de 1778). Si el desertor es de los Cuerpos en campaña de Indias y es arrestado una vez que éstos han vuelto a la Península, se destinará a los Cuerpos fijos de Indias donde cumplirá el castigo (R. O. de 2 de mayo de 1787). El desertor de segunda vez "con la iglesia" -se entendía por tal el individuo que abandonaba el ejército estando en posesión de alguna de las órdenes menores- se destinará sin proceso a los presidios de África por ocho años, y al que «no la tuviese», por diez.

87 Recopilación..., t. XII, págs. 113-118.

${ }_{88}$ Recopilación..., t. XIV, Madrid, 1859, págs. 57-58.

${ }_{89}$ Véase más atrás, Consideración legal de los prófugos y desertores.

so Vid. Decretos del Rey don Fernando VII, t. I, Madrid, 1818, págs. 77-79. 
La misma pena tendrán en Indias y la pasarán en presidios o trabajando en obras públicas. El desertor de primera vez sin circunstancia agravante que no hubiese enajenado prenda alguna del vestuario ni armamento con que se ausentó, y antes de ser descubierto se presente en su regimiento o en cualquier justicia en plazo de ocho días a partir de la fuga, perderá el tiempo que ha servido, empezándole a contar de nuevo desde el día que se presentó, sin perjuicio para optar a premios. El que enajenó prendas estará preso durante cuatro meses a simple socorro y servirá ocho años en su compañía quedándole sólo opción a inválidos. Si vuelve a desertar se le calificará desertor de segunda. Los que sean aprehendidos cuatro días después de su fuga, aunque no hayan salido de la ciudad del regimiento y le hayan pasado dos listas (tarde y rancho de noche y lista y rancho de la mañana) se le dará como conato de deserción y se le impondrá un recargo de cuatro años si el tiempo que le falta no pasa de ocho años (R. O. de 13 de junio de 1789). La vigencia de estas penas será larga, pues permanecerá en vigor varios lustros, aunque algunos de sus extremos se modifiquen; tal ocurre el 8 de julio de 1854, en que, a través del Ministerio de la Guerra, el gobierno declara y ordena lo que sigue:

"Las diversas reales órdenes que desde la publicación de la ordenanza se han expedido imponiendo penas a los desertores sin haber conseguido hacer desaparecer este delito, que destruye $y$ desmoraliza a los Ejércitos, han demostrado la ineficacia de nuestra legislación militar en esta parte, y deseando... que se consolide cada vez más la disciplina en las filas del Ejército, destruyendo los medios que puedan barrenarla... la pena señalada por la Real Orden de 8 de enero de 1815 a los desertores de primera, sin circunstancia agravante, sea en lo sucesivo la de servir en uno de los Cuerpos de Ultramar el tiempo de su empeño, más el que el individuo hubiese estado desertado, por vía de recargo, haciéndose extensiva esta disposición a los prófugos de quintas" ${ }^{91}$.

El Inspector General de Infantería determinará el destino posterior de los desertores capturados o presentados espontáneamente. Dispone que lo primero que se hará con ellos será instruirle la respectiva sumaria para poder calificar su deserción, cuándo se produjo y la fecha de su captura; de esta manera se sabrá el tiempo que estuvo como desertor, que será el que cumplirá de recargo. Si es de los que han de ser trasladados a Ultramar, se remitirá al Inspector General de Infantería una copia de su filiación para que se transmita la orden a la bandera más próxima al lugar donde está enclavado el regimiento, cuyo jefe "solicitará de la autoridad competente el pasaporte y orden correspondiente para la conducción del individuo a su destino". La sumaria instruida se archivará en el Cuerpo y se remitirá la filiación del desertor al Comandante de la Bande-

91 Recopilación..., t. I, págs. 69-70. 
ra a que ha sido destinado, completada con la causa de su baja, fecha de la deserción y la de su captura o presentación» ${ }^{92}$.

Determinada de esta forma la legislación relativa a desertores, el gobierno se percata de que continúa vigente el artículo 39 del Decreto de 9 de enero de 1838, que excluye de la gracia del indulto a los desertores, por lo que se ordena, oído el Tribunal Supremo de Guerra y Marina, que cese el vigor de dicho artículo y que cuantos desertores de primera sin circunstancia agravante $y$ los desertores de segunda que se presenten en el Palacio Real puedan optar al indulto ${ }^{93}$. En Decreto de 31 de agosto de $1846^{94}$ Isabel II dice que las disposiciones contenidas en la Orden de 8 de julio de 1845 comprenden a todos los huidos del ejército, tanto a los que habían desertado antes de esa fecha como a los que lo hiciesen después.

Los castigos más usuales para los desertores eran el recargo en el tiempo de servicio y su destino a Ultramar o al Regimiento Fijo de Ceuta. A los de primera vez se les destinaba originariamente a Cuba y Puerto Rico, luego se les enviaba al Fijo de Ceuta; después fue revocada de nuevo esta disposición y fueron enviados a las provincias americanas, salvo excepciones concedidas por el débil estado de salud que los penados pudieran tener ${ }^{95}$. A los desertores de segunda se les recargaban cuatro años de servicio, según se hizo público en 31 de diciembre de $1855^{96}$.

También se destinará al Fijo de Ceuta a los desertores que huyan a Portugal ${ }^{97}$, a los que se casaran durante su fuga ${ }^{98}$, los procedentes de Milicias Provinciales, siempre y cuando en su deserción no concurran circunstancias agravantes (desertar con armas, con prendas de uniforme o fondos de su unidad, con el caballo, etc.) y sean casados ${ }^{99}$.

Los desertores son condenados a muerte cuando su caso reúne las suficientes agravantes y ponen grandes dificultades para su captura, como en el caso que se notifica el 18 de febrero de 1849, sobre el fusilamiento de tres soldados que desertaron con armas del tercer batallón del

to de 1846.

${ }_{94}$ Ibidem, págs. 158-159.

95 Pueden verse estas alternativas jurídicas en Recopilación..., t. IV, pág, 6; t. VII, págs. 8-9 y 87; t. IX, Madrid, 1854, págs. 11-12.

${ }_{38}$ Recopilación..., págs. 113-114.

97 Recopilación..., t. IV, págs. 151-152; Orden de 30 de octubre de 1849.

98 Recopilación..., t. III, págs. 109-110.

99 Recopilación..., t. VII, pág. 19. 
Regimiento de Asturias y fueron apresados en la provincia de Teruel por la Guardia Civil tras ofrecer una gran resistencia ${ }^{100}$.

La Orden promulgada en 3 de julio de 1848 tiene un origen muy curioso. En Granada unos huidos de la caja de recluta capturaron al prófugo que suplian. Se resuelve que siempre que se presente este caso, los aprehensores serán sentenciados a seis meses de prisión carcelaria o domicilial mantenidos a sus expensas. Este caso hace pensar al gobierno que puede repetirse esta singularidad y la previene la misma Orden de 3 de julio: si unos suplentes, después de desertar y ser capturados, están sirviendo en un Cuerpo de la Península, seguirán en él cumpliendo la pena impuesta cuando se capture a sus sustituidos ${ }^{101}$.

A los quintos desertores de las cajas declarados libres después, se les impuso, según Orden de 3 de julio de 1848, la pena de seis meses de prisión, pena que se hizo extensiva, por Orden de 27 de agosto de 1857, a aquellos que habiendo sido entregados a los Cuerpos, desertaran y fueran declarados libres de servicio ${ }^{102}$. Por último, en 8 de marzo de 1856 se determinó que a los desertores aprehendidos que tengan que quedar a disposición de los tribunales ordinarios por cualquier delito cometido durante su deserción, no se les contará para su empeño el tiempo en que estén dependiendo de tales tribunales ${ }^{103}$.

Sin embargo, tantas precisiones lo que demuestran es, en definitiva, la necesidad de una nueva reglamentación global de las deserciones y su penalización, así como un dispositivo de seguridad más eficaz. La nueva reglamentación se contiene en la Ley de 31 de julio de 1866, cuyos extremos fundamentales, por lo que a las penas se refiere, son los siguientes: el conato de deserción se castiga con un año de recargo en el servicio, que se cumplirá en el mismo cuerpo donde se registre el conato, pena que se mantendrá también en las reincidencias. La primera deserción sin agravantes se castiga con el destino a un Cuerpo de $\mathrm{Cu}$ ba o Puerto Rico para cumplir en él el tiempo de empeño y el recargo del que estuvo desertado. Si el desertor de primera se presenta voluntariamente sólo perderá el tiempo de servicio y continuará en su Cuerpo, a condición de que se presente antes de los ocho días contados a partir del de su deserción. Los conatos de deserción al extranjero en tiempos de paz se castigarán con dos años de recargo en el propio Cuerpo y en tiempos de guerra con cuatro años en el Regimiento Fijo de Ceu-

100 Recopilación..., t. IV, págs. 34-35.

101 Recopilación..., t. III, pág. 109.

102 Recopilación..., t. XII, pág 79.

103 Recopilación..., t. XI, Madrid, 1856, págs 17-18. 
ta más el recargo que se le impusiese y pérdida de tiempo servido hasta entonces.

La deserción al extranjero en tiempos de paz entraña la pérdida del tiempo servido y el destino a Filipinas, donde cumplirá su empeño y un recargo de cuatro años; si se presenta antes de los ocho días, el castigo será el mismo, excepto menos el destino a Filipinas. En tiempos de guerra, será fusilado, salvo si se le sorprende en dirección a retaguardia, caso en que se le penará con el destino a Cuba o Puerto Rico, con pérdida del tiempo servido, de todos los premios y condecoraciones, más un recargo de seis años. El soldado que deserte estando de centinela será pasado por las Armas, y si lo hiciera estando de guardia será enviado a presidio para cumplir el tiempo de empeño que le falte y un recargo de cuatro años, pena que se agravaba en ciertos casos. El soldado cumplido que deserte, cumplirá dos años más de recargo.

"Cuando el desertor de primera cometa un delito común", lo juzgará y penará un tribunal ordinario y luego un tribunal militar por el delito de deserción, salvo que la pena impuesta sea de las que inhabilitan para volver al ejército, en cuyo caso cumplirá en presidio lo que le resta de empeño. "La segunda deserción... será penada con ocho años de presidio, pérdida de todas las ventajas adquiridas, y prohibición absoluta de volver a filas. Si el desertor fuese de los indultados de primera, serán nueve años de recargo en vez de los ocho impuestos a los que no tienen esta circunstancia... Si la segunda deserción fuese acompañada de delitos comunes más o menos graves, será juzgado el desertor por el tribunal que corresponda, como queda dispuesto en la primera deserción para iguales casos, y entonces extinguirá en presidio los ocho años por que está penado. Los conatos y las deserciones consumadas se anotarán en la filiación del interesado, así como la pena que se le ha impuesto" "104.

Esta disposición invalida todas las anteriores y organiza uno de los aspectos más profusos de la legislación militar. Su vigencia será grande y servirá de base a cualquier reforma posterior. Habrá que esperar hasta el Código Penal del Ejército de 1884 para encontrar una nueva reglamentación global de la deserción, en la que cabe destacar la desaparición de la pena de muerte (salvo para los que deserten en tiempos de guerra en dirección al enemigol, la elevación de los tiempos de recargo y la previsión de la deserción en la oficialidad ${ }^{105}$.

104 Garcia Martin, op. cit., págs. 168-170.

105 Gaceta, 21 de noviembre de 1884. 
Como vemos, el reclutamiento constituye una de las notas dominantes de la España decimonónica, y durante las décadas centrales del siglo, coincidiendo casi con la vigencia de la Constitución de 1845 , va a perfilar algunos de sus rasgos más impopulares, convirtiéndolo, a la postre, en injusto e indeseable. La respuesta a esa situación, el deseo de escapar a ella, se manifiesta a nivel individual mediante los prófugos y los desertores, dos tipos delictivos que merecen una atención constante sin que llegue a erradicarse su práctica. En este sentido, se puede decir que uno de los problemas pendientes de la España de ese tiempo fue precisamente el que nos ha ocupado en estas páginas. Tendrían que cambiar, $y$ mucho, las condiciones sociales y económicas del país y la propia normativa del reclutamiento militar para que estos males empezaran a paliarse y llegaran a desaparecer prácticamente. Pero por entonces la realidad era otra muy distinta y el mismo ordenamiento constitucional permitía la realidad que hemos conocido, por cuanto el artículo 6. de la Constitución de 1845 imponía a los españoles la obligación de defender a su país cuando fueran requeridos para ello, prescripción presente también en las demás constituciones decimonónicas y en donde se apoyaban en última instancia las celebraciones de quintas. 